Article

\title{
Establishment of a Cell Suspension Culture of Ageratina pichinchensis (Kunth) for the Improved Production of Anti-Inflammatory Compounds
}

\author{
Mariana Sánchez-Ramos ${ }^{1}$, Laura Alvarez ${ }^{2}{ }^{\oplus}$, Antonio Romero-Estrada ${ }^{3}$, \\ Antonio Bernabé-Antonio ${ }^{3}(\mathrm{D})$, Silvia Marquina-Bahena ${ }^{2, *}$ and Francisco Cruz-Sosa ${ }^{1, *(D)}$ \\ 1 Departamento de Biotecnología, Universidad Autónoma Metropolitana-Iztapalapa, San Rafael Atlixco 186, \\ Col. Vicentina 09340 Ciudad de México, Mexico; marianasan_06@hotmail.com \\ 2 Centro de Investigaciones Químicas-IICBA, Universidad Autónoma del Estado de Morelos, \\ Avenida Universidad 1001, Col. Chamilpa 62209 Cuernavaca, Morelos, Mexico; lalvarez@uaem.mx \\ 3 Departamento de Madera, Celulosa y Papel, Centro Universitario de Ciencias Exactas e Ingenierías, \\ Universidad de Guadalajara, Km. 15.5, Carretera Guadalajara-Nogales, Col. Las Agujas 45020 Zapopan, \\ Jalisco, Mexico; are@uaem.mx (A.R.-E.); bernabe_aa@hotmail.com (A.B.-A.) \\ * Correspondence: smarquina@uaem.mx (S.M.-B.); cuhp@xanum.uam.mx (F.C.-S.)
}

Received: 20 August 2020; Accepted: 6 October 2020; Published: 21 October 2020

\begin{abstract}
Ageratina pichinchensis (Kunth) is a plant used in traditional Mexican medicine to treat multiple ailments. However, there have not been biotechnological studies on producing compounds in in vitro cultures. The aim of this study was to establish a cell suspension culture of A. pichinchensis, quantify the anti-inflammatory constituents 2,3-dihydrobenzofuran (2) and 3-epilupeol (3), evaluate the anti-inflammatory potential of its extracts, and perform a phytochemical analysis. Cell suspension cultures were established in a MS culture medium of 30-g L ${ }^{-1}$ sucrose, $1.0-\mathrm{mg} \mathrm{L}^{-1} \alpha$-naphthaleneacetic acid, and 0.1-mg L ${ }^{-1}$ 6-furfurylaminopurine. The ethyl acetate extract of the cell culture analyzed by gas chromatography (GC) revealed that the maximum production of anti-inflammatory compounds 2 and 3 occurs on days eight and 16, respectively, improving the time and previously reported yields in callus cultures. The anti-inflammatory activity of these extracts exhibited a significant inhibition of nitric oxide (NO) production. Furthermore, a phytochemical study of the ethyl acetate (EtOAc) and methanol $(\mathrm{MeOH})$ extracts from day 20 led to the identification of 17 known compounds. The structures of the compounds were assigned by an analysis of 1D and 2D NMR data and the remainder by GC-MS. This is the first report of the production of (-)-Artemesinol, (-)-Artemesinol glucoside, encecalin, and 3,5-diprenyl-acetophenone by a cell suspension culture of A. pichinchensis.
\end{abstract}

Keywords: cell suspension culture; anti-inflammatory activity; phytochemical analysis

\section{Introduction}

The genus Ageratina (Asteraceae) consists of about 1200 species and is distributed in temperate and subtropical regions of the America, Europe, Africa, and Asia [1-4]; in Mexico, about 164 species of Ageratina have been reported [5,6]. Several species of this genus have been studied, and these studies have demonstrated bactericidal, antifungal, antiviral, analgesic, cytotoxic, and anti-inflammatory effects, as well as the ability to treat gastric ulcers [7-12]. In the state of Morelos, Mexico, Ageratina pichinchensis is traditionally used to treat gastric ulcers and heal deep wounds. Phytochemically, the aerial parts of $A$. pichinchensis are characterized by containing sterols, triterpenes, benzochromenes, and benzofurans [13,14]. The benzochromenes isolated from $A$. pichinchensis showed insecticidal [12], antifungal $[15,16]$, and gastroprotective activities [17]. However, the production of these compounds can be unsustainable through the large-scale planting of $A$. pichinchensis, because many secondary 
metabolites tend to vary their production according to climatic fluctuations, as has happened with other species [18].

Numerous studies have shown that plant cell cultures could play an appropriate role in the constant and controlled production of bioactive compounds [19-23]. For example, the production of the anticancer anthraquinone shikonin is obtained in $1-2 \%$ yield from the roots of the Asian plant Lithospermum erythrorhizon; however, its production depends on the geographical distribution and climate, and in addition, the wild plant requires five-seven years of growth for its production, while cultivated plant cells can produce 12-20\% [24-26]. Examples like this support the use of plant cells to produce value-added compounds.

Recently, our research group reported the isolation and anti-inflammatory effect of (2S,3R)-5-acetyl-7,3 $\alpha$-dihydroxy-2 $\beta$-(1-isopropenyl)-2,3-dihydrobenzofuran (2) and 3-epilupeol (3) from the ethyl acetate extract of a callus culture of $A$. pichinchensis [27].

In this study, we established a cell suspension culture of $A$. pichinchensis and improved the production of compounds 2 and 3. Furthermore, the extracts were evaluated for their anti-inflammatory activity. The phytochemical analysis of the ethyl acetate and methanol extracts of this culture allowed for the isolation and identification of 17 known accumulated compounds, including the anti-inflammatory compounds 2 and 3 . Some of the identified compounds have been described as having anti-inflammatory and antimicrobial activity.

\section{Results and Discussion}

\subsection{Cell Suspension Culture and Growth Kinetics}

It has been shown that the friable callus is most suitable for the establishment of cell suspension cultures of any plant species. A. pichinchensis cells that transferred to Murashige and Skoog (MS) liquid culture medium with the same growth regulators as in callus cultures (1.0-mg $\mathrm{L}^{-1} \alpha$-naphthaleneacetic acid (NAA) and 0.1-mg L ${ }^{-1}$ 6-furfurylaminopurine (KIN)) grew easily, showing abundant biomass and a slightly yellowish appearance (Figure 1a-c).

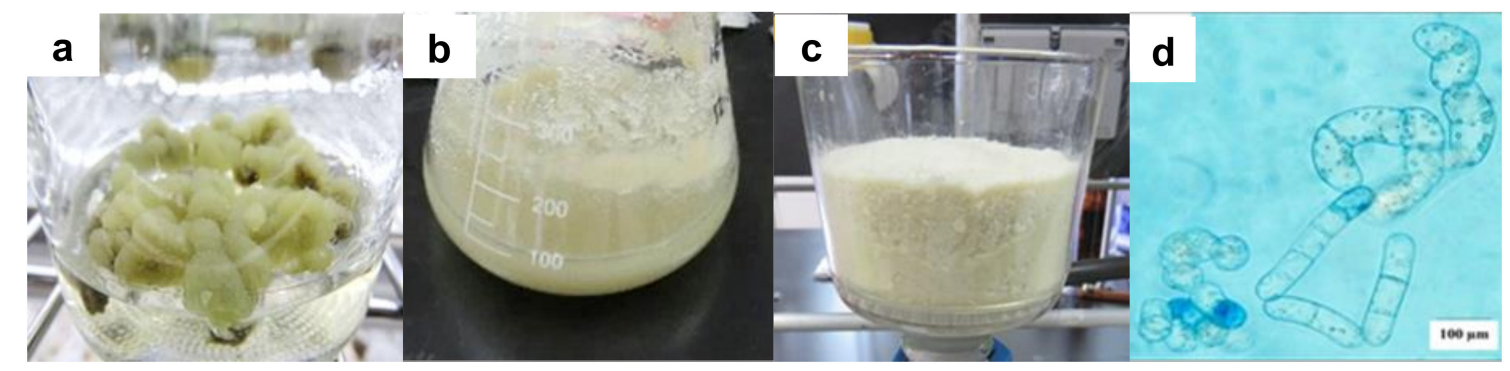

Figure 1. Cell culture from Ageratina pichinchensis leaves. (a) Friable callus at 20 days of culture;

(b) cell suspension culture with abundant biomass at 16 days of culture; (c) filtered biomass;

(d) microscopic image of cell suspension culture (100x).

Similar results were observed in cell suspension cultures of Stevia rebaudiana that were disintegrated within seven days, and the cells also acquired a yellowish appearance [28]. In this study, the cell growth of A. pichinchensis was faster (22 days) in the MS liquid culture medium than in callus cultures; in contrast, callus reached their maximum growth after 30-40 days [27]. This might be caused by the facilitated absorption of nutrients in the liquid medium [29].

The growth kinetic of $A$. pichinchensis cell suspension cultures was maintained for 22 days, during which it showed a typical growth curve (Figure 2). The growth kinetic was characterized by a lag phase of four days, reaching 2.37-g L ${ }^{-1}$ dry weight (DW); subsequently, the cells entered the exponential phase and lasted until day 16. During this time, a maximum biomass accumulation was observed (13.28-g L $\left.{ }^{-1}\right)$ of about 5.6-fold the initial dry weight. The specific growth rate $(\mu)$ was 
0.20 days $^{-1}$, and doubling time (Dt) was 3.01 days $^{-1}$ until reaching a stationary phase, in which the cell culture showed a brown appearance and decreased growth (Figure 2).

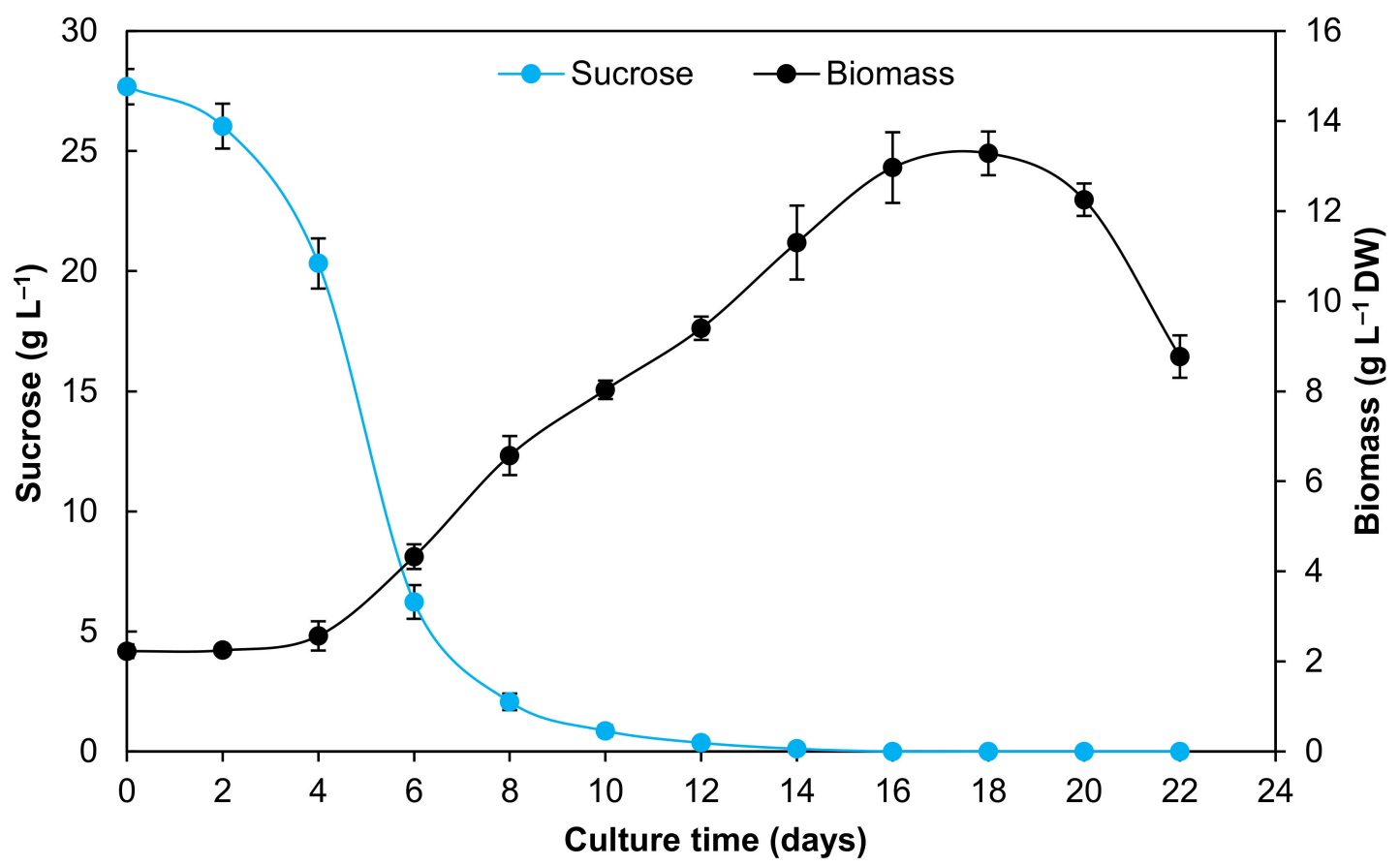

Figure 2. Growth kinetics and consumption of sucrose of the A. pichinchensis cell suspension culture during growth for 22 days in Murashige and Skoog (MS) medium with 1.0-mg L ${ }^{-1} \alpha$-naphthaleneacetic acid (NAA) and 0.1-mg L ${ }^{-1}$ 6-furfurylaminopurine (KIN).

Regarding the consumption of total sugars, an abrupt decrease in the sugar content was observed until day six, but the biomass increased; the remainder of the sugar was stable after day 14 (Figure 2), perhaps due to the consumption of nutrients and lack of oxygen in the medium [30,31].

The growth kinetics is similar to that for Spilanthes acmella, in which the cell suspension culture reached a specific growth rate of 0.28 days $^{-1}$; during the exponential phase, the doubling time was 2.50 days $^{-1}$, and the maximum biomass was $8.5-\mathrm{g} \mathrm{L}^{-1}$ at day 15 [32]. On the other hand, Satureja khuzistanica cell suspension cultures reached a maximum dry biomass of $19.7-\mathrm{g} \mathrm{L}^{-1}$ at 21 days, with a specific growth rate of 1.5 days $^{-1}$ and a doubling time of 7.6 days $^{-1}$ [33]. Similarly, cell suspension cultures of Helianthus annuus produced $12.7-\mathrm{g} \mathrm{L}^{-1}$ dry biomass after nine days of culture, showing a specific growth rate of 0.21 days $^{-1}$ and a doubling time of 3.31 days $^{-1}$ [34]. These results suggest that $A$. pichinchensis cell cultures have a similar tendency as other cell suspension cultures, and, although the biomass yield differs for each species, it can also be produced in a short time.

\subsection{Cell Viability and $\mathrm{pH}$ in the Culture Medium}

Cell viability was suitable in the cell suspension culture, decreasing only slightly during the 22 days of culture. On the first day of culture, $89.57 \%$ of the viability was present, and by 22 days, it only decreased to $77.19 \%$ (Figure 3).

These results confirm that the establishment of the A. pichinchensis cell suspension culture was successful since the viability was greater than $50 \%$. In other species, such as Taxus globose, the viability decreases to $45-50 \%$ at the end of the growth culture [35], which was lower than that of the A. pichinchensis culture. The microscopic image shows that the A. pichinchensis cell suspension culture produced single cells and some small aggregates (Figure 1d). In a study conducted in Taxus cuspidate cell cultures [35], it was found that the size of cell aggregates is important, since at average sizes greater 
than $800 \mu \mathrm{m}$, there is a decrease in the production of paclitaxel; however, in our study, the aggregates were smaller (Figure 1d).

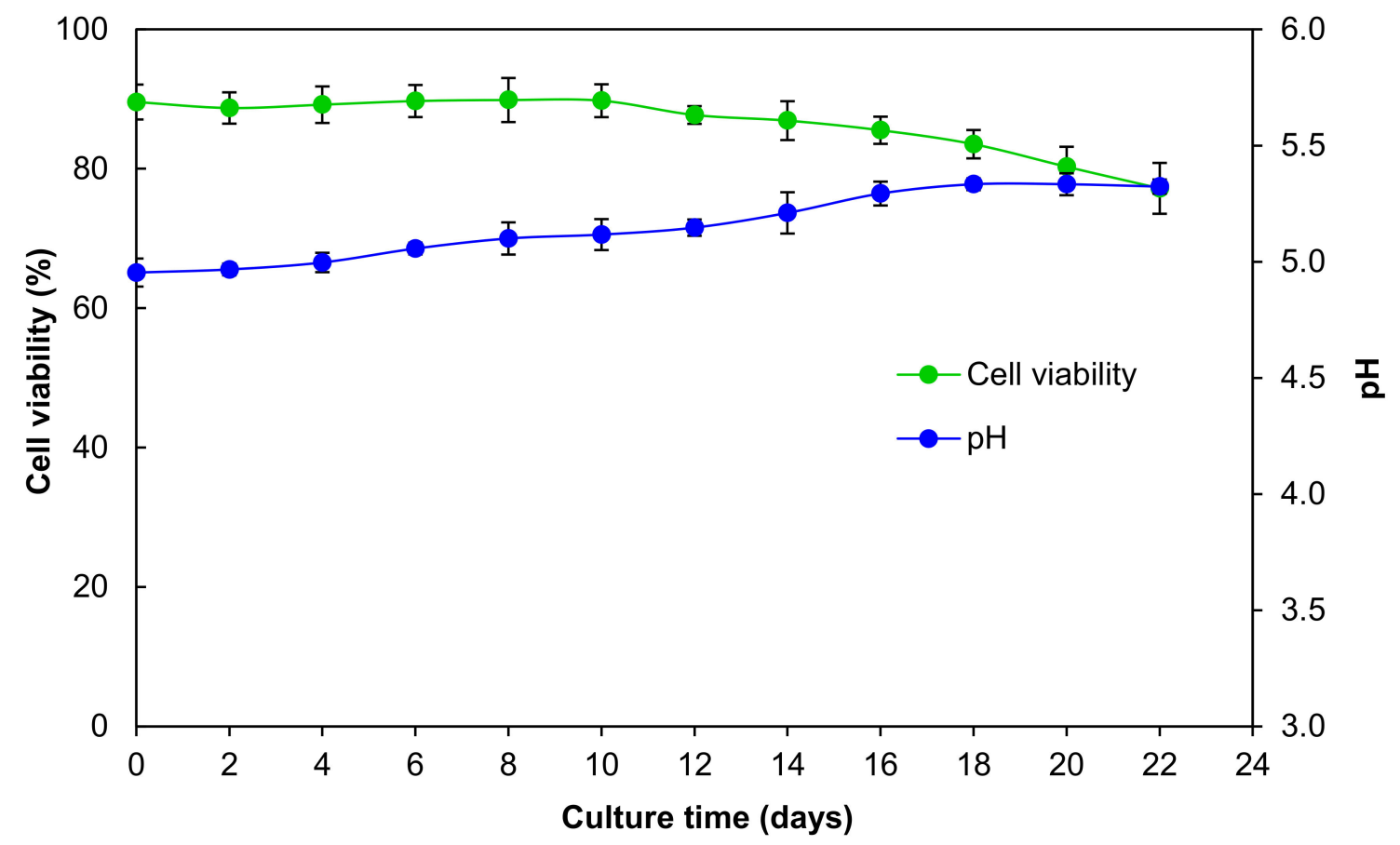

Figure 3. Viability of the cell suspension culture and $\mathrm{pH}$ of the culture medium over 22 days of culture growth of $A$. pichinchensis.

On the other hand, there was a gradual increase in the $\mathrm{pH}$ values (5.0-5.3) during the exponential phase (from day four to 18); later, between days 18 and 22, the $\mathrm{pH}$ values remained stable at 5.3, but these changes did not affect the biomass or the production of compounds 2 and 3 during the growth kinetics. Likewise, the cell viability experienced a similar behavior; at the beginning of the kinetics, the cell viability was $89 \%$, remaining stable until day 10 (exponential phase), and on subsequent days, a gradual decrease was observed up to $77 \%$, possibly as a consequence of the depletion of nutrients and alkalinization of the culture medium (Figure 3).

In cell suspension cultures of Dioscorea deltoidea, there was an acidification of the culture medium during the lag phase, an alkalization during the exponential phase, and a steady state of $\mathrm{pH}$ in the stationary phase. At the same time, the exponential growth of the cell culture medium may be associated with the development of alkaline reactions that occur during metabolism [36]. The observed changes in $\mathrm{pH}$ values may be related to the use of ammonium and nitrate or the absorption of sugar by the transport mechanism with $\mathrm{H}^{+}$[37]. Moreover, plant cells can also modify the external $\mathrm{pH}$; they can increase or decrease the values according to the $\mathrm{pH}$ range in which they are grown, until a balance is produced [38].

\subsection{Phytochemical Analysis of the Cell Suspension Cultures}

The phytochemical analysis of the ethyl acetate (EtOAc) and methanol (MeOH) extracts obtained from the biomass on day 20 led to the identification of 17 known compounds (Figure 4), including the benzochromenes: desmethoxyencecalin (1), (-)-Artemesinol (6), (-)-Artemesinol glucoside (7), and encecalin (10); three triterpenes: 3-epilupeol (3), 24-metilene-9,19-cyclolanastan-3 $\beta$-ol (8), and 24-methylenecycloartan-3-one (9); two sterols: $\beta$-sitosterol (4) and stigmasterol (5); the benzofuran (2S,3R)-5-acetyl-7,3 $\alpha$-dihydroxy-2 $\beta$-(1-isopropenyl)-2,3-dihydrobenzofuran (2); the 3,5-diprenyl-acetophenone (11); the fatty acids: palmitic acid (12), hexadecenoic acid, methyl ester (13), isopropyl palmitate (14), palmitamide (15), and oleamide (16); and the amino acid derivative 
methyl pyroglutamate (17). Compounds $1-5$ and 10-14 were identified in the ethyl acetate extract. Compounds 1-5 were isolated by column chromatography, as described in Section 3.4, and identified by an analysis of their ${ }^{1} \mathrm{H}$ and ${ }^{13} \mathrm{C}-\mathrm{NMR}$ data (Figures S1-S6) and compared with the literature data [27]. Compounds 10-14 were identified by gas chromatography coupled with mass spectrometry (GC-MS) analysis (NIST 1.7a). Compounds 4 and 5 and 10 and 11 were previously reported as constituents of the aerial parts of $A$. pichinchensis $[15,17]$, while compounds $1-3$ and 12 and 13 were previously reported in a callus culture of $A$. pichinchensis [27].<smiles>CC(=O)c1ccc2c(c1)C=CC(C)(C)O2</smiles>

Desmethoxyencecalin (1)<smiles>C=C(C)c1oc2c(O)cc(C(C)=O)cc2c1O</smiles>

$(2 S, 3 R)$-5-Acetyl-7,3 $\alpha$-dihydroxy- $2 \beta-$ (1-isopropenyl)-2,3-dihydrobenzofuran (2)

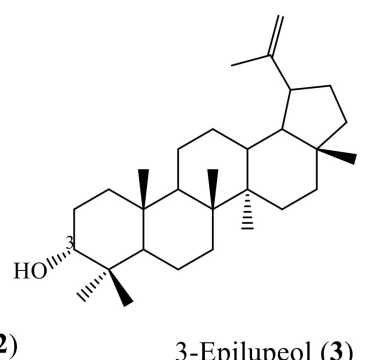

3-Epilupeol (3)<smiles>CC[C@H](C=C[C@@H](C)C1CCC2C3CC=C4C[C@@H](O)CC[C@]4(C)C3CC[C@@]21C)C(C)C</smiles>

Stigmasterol
$\beta$-sitosterol

\section{(4) $\begin{array}{cc}22 & \mathbf{2 3} \\ \mathrm{H} & \mathrm{H}\end{array}$} (5) $\mathrm{CH}_{2} \quad \mathrm{CH}_{2}$<smiles>[R]C[C@]1([2H])C=Cc2cc(C(C)=O)ccc2O1</smiles>

(6) $\mathrm{OH}$

(7) $\beta$-Gluc- (-)-Artemesinol glucoside

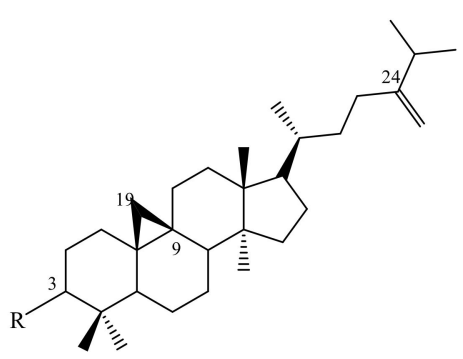

$\mathrm{R}$

(8) $\mathrm{OH}$ 24-Methylene-9,19-cyclolanastan-3 $\beta$-ol

(9) $=$ O 24-Methylenecycloartan-3-one<smiles>[R]C(=O)CCCCC</smiles>

$\mathrm{R}$

(12) $\mathrm{OH} \quad$ Palmitic acid

(13) OMe Hexadecanoic acid, methyl ester

(14) O-isopropyl Isopropyl palmitate<smiles>CCCCC(N)=O</smiles>

Palmitamide (15)

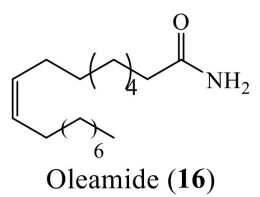<smiles>CC(=O)c1cc(CC=C(C)C)c(O)c(CC=C(C)C)c1</smiles>

3,5-diprenyl-acetophenone (11)<smiles>COC(=O)[C@@H]1CCC(=O)N1</smiles>

Methyl pyroglutamate (17)

Figure 4. Chemical structures of compounds identified in the cell suspension culture of A. pichinchensis.

The $\mathrm{MeOH}$ extract was fractionated by column chromatography (as described in Section 3.4), and from the chromatographic work, five groups of fractions were obtained (MSR-M-1 to MSR-M-5). The MSR-M-1 group was analyzed by GC-MS, and compounds 15-17 were identified. The MSR-M-2 and MSR-M-3 groups were purified by column chromatography. From these groups, compounds 1 and 
2 were isolated and identified in mixtures of 4 and 5. The MSR-M- 4 group, subjected to a purification process, allowed for obtaining three groups of fractions: MSR-M-4A (1-32; $21.2 \mathrm{mg})$, MSR-M-4B (33-42; $32.7 \mathrm{mg})$, and MSR-M -4C (43-68; $48.4 \mathrm{mg})$. The MSR-M-4A group was analyzed by GC-MS, and compounds 8 and 9 were identified. The MSR-M-4B group was subjected to silica gel column chromatography, and compound 6 was obtained as a semisolid mass. The ${ }^{1} \mathrm{H}-\mathrm{NMR}$ spectrum of (6) displayed three signals at $\delta 1.30\left(3 \mathrm{H}, \mathrm{s}, \mathrm{CH}_{3}-13\right), \delta 2.44\left(3 \mathrm{H}, \mathrm{s}, \mathrm{CH}_{3}-12\right)$, and $\delta 3.53\left(2 \mathrm{H}, \mathrm{s}, \mathrm{CH}_{2}-14\right)$, which suggest the presence of $\mathrm{CH}_{3}-, \mathrm{CH}_{3} \mathrm{CO}$, and $-\mathrm{CH}_{2} \mathrm{OH}$ groups in the skeleton. In the aromatic proton region, signals of an ABX system at $\delta 7.65(1 \mathrm{H}, \mathrm{dd}, J=8.4,2.2 \mathrm{~Hz}, \mathrm{H}-7), \delta 7.51(1 \mathrm{H}, \mathrm{d}, J=2.2 \mathrm{~Hz}$, $\mathrm{H}-5)$, and $\delta 6.73(1 \mathrm{H}, \mathrm{d}, J=8.5 \mathrm{~Hz}, \mathrm{H}-8)$ indicated the presence of a three-substituted aromatic ring. The olefinic AB system at $\delta 5.58(1 \mathrm{H}, \mathrm{d}, J=10 \mathrm{~Hz}, \mathrm{H}-4)$ and $\delta 6.40(1 \mathrm{H}, \mathrm{d}, J=10 \mathrm{~Hz}, \mathrm{H}-3)$ established the presence of a double bond with cis-configuration (Figure S7). Moreover, the ${ }^{13} \mathrm{C}-\mathrm{NMR}$ spectrum (Figure S8) showed 13 signals, including an acetoxy carbonyl carbon $(\delta 196.84 ; C O)$; two oxygenated carbons ( $\delta 80.86$ and $68.99 ; \mathrm{CO}$ and $\left.\mathrm{CH}_{2} \mathrm{OH}\right)$; five methine protons at $\delta 127.94,130.97,127.45,116.67$, and 124.32 (C-7, C-3, C-5, C-4, and C-8); four quaternary carbons at $\delta 157.38,130.21,120.64$, and 80.86 (C-9, C-6, C-10, and C-2); and two methyl groups in $\delta 26.32$ and 23.49 (C-12 and C-13). According to the data obtained for ${ }^{1} \mathrm{H}$ and ${ }^{13} \mathrm{C}-\mathrm{NMR}$, compound 6 was characterized as (-)-Artemesinol (6) [39]. Compound 7 was obtained as a semi-solid mass from the MSR-M-4C fractions group. The ${ }^{1} \mathrm{H}-\mathrm{NMR}$ spectrum of (7) displayed signals at $\delta 1.30\left(3 \mathrm{H}, \mathrm{s}, \mathrm{CH}_{3}-13\right), \delta 2.44\left(3 \mathrm{H}, \mathrm{s}, \mathrm{CH}_{3}-12\right), \delta 3.91(1 \mathrm{H}, \mathrm{d}$, $J=10.6 \mathrm{~Hz}, \mathrm{H}-14 \mathrm{a}), \delta 3.58(1 \mathrm{H}, \mathrm{d}, J=10.7 \mathrm{~Hz}, \mathrm{H}-14 \mathrm{~b})$, and a symmetric AB system at $\delta 5.67(1 \mathrm{H}, \mathrm{d}$, $J=10 \mathrm{~Hz}, \mathrm{H}-3)$ and $6.42(1 \mathrm{H}, \mathrm{d}, J=10 \mathrm{~Hz}, \mathrm{H}-4)$, as well as hydrogens in the aromatic region at $\delta 7.69$ $(1 \mathrm{H}, \mathrm{dd}, J=8.4,2.2 \mathrm{~Hz}, \mathrm{H}-7), 7.56(1 \mathrm{H}, \mathrm{d}, J=2.2 \mathrm{~Hz}, \mathrm{H}-5)$, and $6.77(1 \mathrm{H}, \mathrm{d}, J=8.5 \mathrm{~Hz}, \mathrm{H}-8)$.

The ${ }^{1} \mathrm{H}$, correlated spectroscopy (COSY), DEPT, and ${ }^{13} \mathrm{C}-\mathrm{NMR}$ (Figures S9-S12) displayed a compound similar to (-)-Artemesinol (6) but with the additional presence of a pyranose sugar moiety at $\delta 4.46\left(1 \mathrm{H}, \mathrm{d}, J=7.8 \mathrm{~Hz}, \mathrm{H}-1^{\prime}\right)$ and $\delta 3.87-3.18\left(6 \mathrm{H}, \mathrm{m}, \mathrm{H}-2^{\prime}{ }^{\prime}\right.$ to $\left.\mathrm{H}-6^{\prime}\right)$. The chemical shift of the proton at $\mathrm{H}-\mathrm{l}^{\prime}(\delta 4.46)$ and the coupling constant $J^{1^{\prime}, 2}$ of $7.8 \mathrm{~Hz}$ indicated that the glycosidic bond is $\beta$-configured. The direct connections between the protons and carbons were identified by the heteronuclear single quantum correlation (HSQC) spectrum (Figure S13). In the heteronuclear multiple bond correlation (HMBC) spectrum (Figure S14), the glycosidic linkage was located at C-14, based on the correlations between $\mathrm{H}^{-1} 1^{\prime}\left(\delta_{\mathrm{H}} 4.46,1 \mathrm{H}, \mathrm{d}, J=7.8 \mathrm{~Hz}\right)$ and $\mathrm{C}-14\left(\delta_{\mathrm{C}} 75.19\right)$, as well as the hydrogens $\mathrm{H}-14 \mathrm{a}\left(\delta_{\mathrm{H}} 3.91,1 \mathrm{H}, \mathrm{d}, J=10.6 \mathrm{~Hz}\right)$ and $\mathrm{H}-14 \mathrm{~b}\left(\delta_{\mathrm{H}} 3.58,1 \mathrm{H}, \mathrm{d}, J=10.7 \mathrm{~Hz}\right)$, with $\mathrm{C}-2\left(\delta_{\mathrm{C}} 79.95\right), \mathrm{C}-13$ $\left(\delta_{\mathrm{C}} 23.79\right)$, and $\mathrm{C}-3\left(\delta_{\mathrm{C}} 127.77\right)$. The optical rotation $\left(\alpha_{) \mathrm{D}}=-8.3^{\circ}\left(\mathrm{c} 0.8, \mathrm{CH}_{3} \mathrm{OH}\right)\right.$ suggests a relative $R$ configuration for $\mathrm{C}-2$ of compound 7 . The evidence indicates that the structure of compound 7 is 6-acetyl-(S)-2-methyl-2-(R)-glucopyranosyl chromene or Artemesinol glucopyranoside [40]. It is important to note that the $1 \mathrm{D}\left({ }^{13} \mathrm{C}, \mathrm{DEPT}\right)$ and $2 \mathrm{D}$ NMR data (COSY, HSQC, and HMBC) of compound 7 have not been described in the literature. Minority compounds (8-11), identified in the A. pichinchensis cell culture, have been employed in cosmetic preparations [17,41-43].

\subsection{Production of Bioactive Compounds During Growth Kinetics}

The GC-MS analysis of the EtOAc extract obtained from the biomass of the $A$. pichinchensis cell suspension culture indicated that the main bioactive compounds (2S,3R)-5-acetyl-7,3 $\alpha$-dihydroxy-2 $\beta$-(1-isopropenyl)-2,3-dihydrobenzofuran (2) and 3-epilupeol (3) are produced during all growth phases (Figure 5 ).

The quantification of compounds 2 and 3 was performed by analyzing the peaks at the retention time $(\mathrm{RT})=20.67 \mathrm{~min}$ (compound 2) and $38.70 \mathrm{~min}$ (compound 3); the molecular ion peaks were observed at $\mathrm{m} / \mathrm{z}=234$ for 2 and 426 for 3 in GC-MS (Figures S19 and S20). The production of compound 2 started from the lag phase, and the maximum production $\left(510.75 \pm 29.10-\mu \mathrm{g} \mathrm{g}{ }^{-1} \mathrm{DW}\right)$ occurred on day eight of the exponential phase; then, it gradually decreased until day 22. Similar results were observed in Capsicum chinense Jacq. cell suspension cultures, in which the capsaicin compound reached a maximum production of 567.4- $\mathrm{\mu g} \mathrm{g}^{-1} \mathrm{DW}$ at 25 days [31]. On the other hand, in Celosia cristata cell 
suspension cultures, betalaine production was observed at the beginning of the exponential phase and then decreased, remaining stable during the exponential and stationary phases [30].

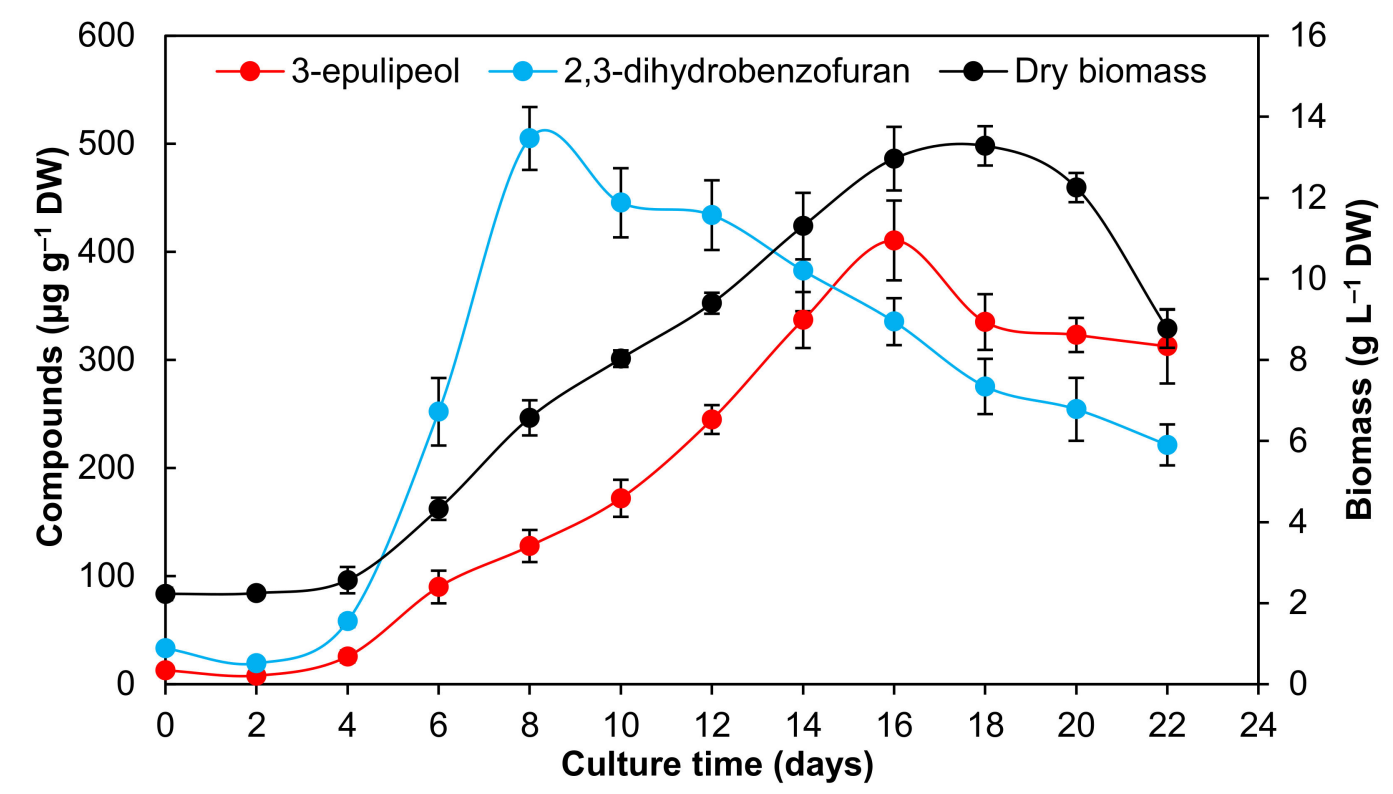

Figure 5. Relationship between the production of 2,3-dihydrobenzofuran and 3-epilupeol and the culture growth of $A$. pichinchensis over 22 days. DW: dry weight.

Regarding the 3-epilupeol compound (3), an association with the culture growth was observed, obtaining its maximum yield (410.59 $\left.\pm 36.91-\mu \mathrm{g} \mathrm{g}^{-1} \mathrm{DW}\right)$ at day 16 (Figure 5). Likewise, the production of the fatty acid amide spilanthol by cell suspension cultures of Spilanthes acmella Murr. presented a trend associated with its growth, reaching a maximum yield during the exponential phase and, subsequently, decreasing rapidly due to the lack of nutrients and consequent cellular death [32]. In another species, Eurycoma longifolia, it was reported that cell suspension cultures produce the quassinoid eurycomanone; this also occurs from the beginning of the growth kinetics, reaching a maximum amount of 1.7- $\mathrm{mg} \mathrm{g}^{-1} \mathrm{DW}$ [44].

These results surpass those reached by callus cultures, whose maximum production was identified on day 30, producing 650- $\mu \mathrm{g} \mathrm{g}^{-1} \mathrm{DW}$ for compound 2 and 201.10- $\mu \mathrm{g} \mathrm{g}^{-1} \mathrm{DW}$ of compound 3 [27]. Reducing the time of production of the compounds is a desirable characteristic in cell suspension cultures; in addition to being more homogeneous compared to callus cultures, it is possible to increase the production of bioactive compounds by adding elicitors and by scaling up reactors [45-47].

On the other hand, encecalin (10) (m/z 232, RT = $18.5 \mathrm{~min}$ ) and 3,5-diprenyl-1,4-hydroxyacetophenone (11) $(\mathrm{m} / \mathrm{z} 272, \mathrm{RT}=21.87 \mathrm{~min})$ were detected in very low concentrations during the exponential phase (day eight) (Figure 6). Antifungal, gastroprotective, and antinociceptive effects were reported for compounds 10 and $11[17,43]$. The highlight of both compounds is that their production on in vitro cultures was reported for the first time. Based on the importance of its biological effects, cell suspension cultures of $A$. pichinchensis are a useful alternative for the production of compounds 10 and 11 , which could be increased by inductors.

\subsection{In Vitro Anti-Inflammatory Activity}

The anti-inflammatory activity of the ethyl acetate extracts of the biomass of the A. pichinchensis suspension cell culture was assessed at different times of the growth kinetics: day 8 (D8), day 12 (D12), and day 16 (D16). Firstly, the extracts were evaluated for their effect on the viability of RAW 264.7 cells at different concentrations $\left(5,10,20,30\right.$, and $\left.40-\mu g \mathrm{~mL}^{-1}\right)$. No extracts exhibited a significant reduction 
in the viability of macrophages compared with the control group, while the positive control (etoposide) showed a significant reduction in the cellular viability at $40-\mu \mathrm{g} \mathrm{mL}{ }^{-1}$ (Figure 7).

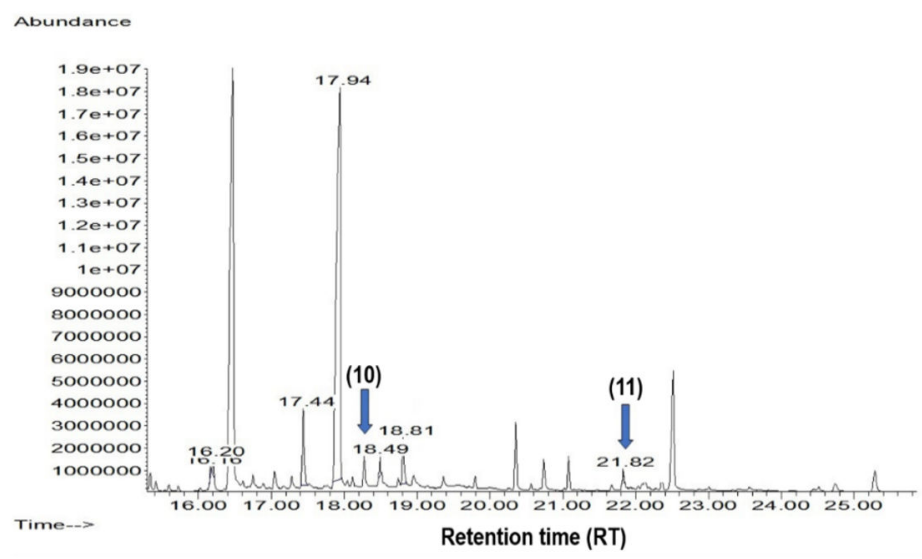

Figure 6. Gas chromatography coupled with mass spectrometry (GC-MS) chromatogram of the ethyl acetate extract from day 8 of the suspension cell cultures, showing the encecalin (10) and 3,5-diprenyl-4-hydroxyacetophenone (11) compounds.
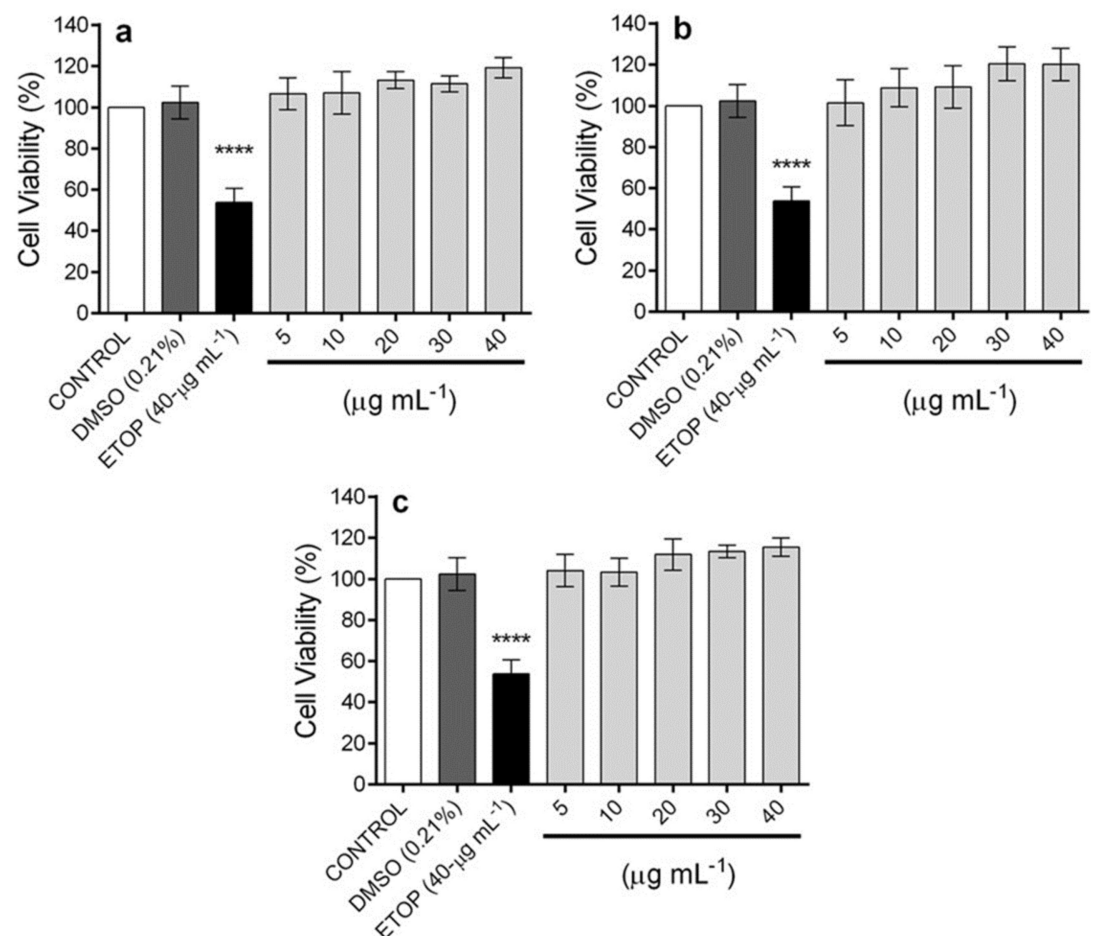

Figure 7. Effect of ethyl acetate extracts from A. pinchichensis cell suspension cultures on the viability of RAW 264.7 cells. (a) extract from day 8 (D8); (b) extract from day 12 (D12); (c) extract from day 16 (D16). The values are expressed as the mean \pm SD of three independent experiments $(n=3)$. Significance was determined using ANOVA, followed by Dunnett's multiple comparisons test $\left(^{* * * *} p<0.0001\right.$ dimethyl sulfoxide (DMSO), ETOP (etoposide), and extracts compared with the control group).

To assess the effect of the extracts from D8, D12, and D16 on nitric oxide (NO) production in lipopolysaccharide (LPS)-stimulated RAW 264.7 cells, cells were treated with the extracts at the same concentrations used in the viability assay. It was reported that LPS, an essential component of the outer membrane of Gram-negative bacteria, can induce inflammatory responses in RAW 264.7 macrophages to produce proinflammatory molecules such as NO [48,49]. The experimental results showed that the 
NO level was increased in LPS-stimulated RAW cells, and this effect was decreased significantly by treatment with extracts at the concentrations tested (Figure 8).
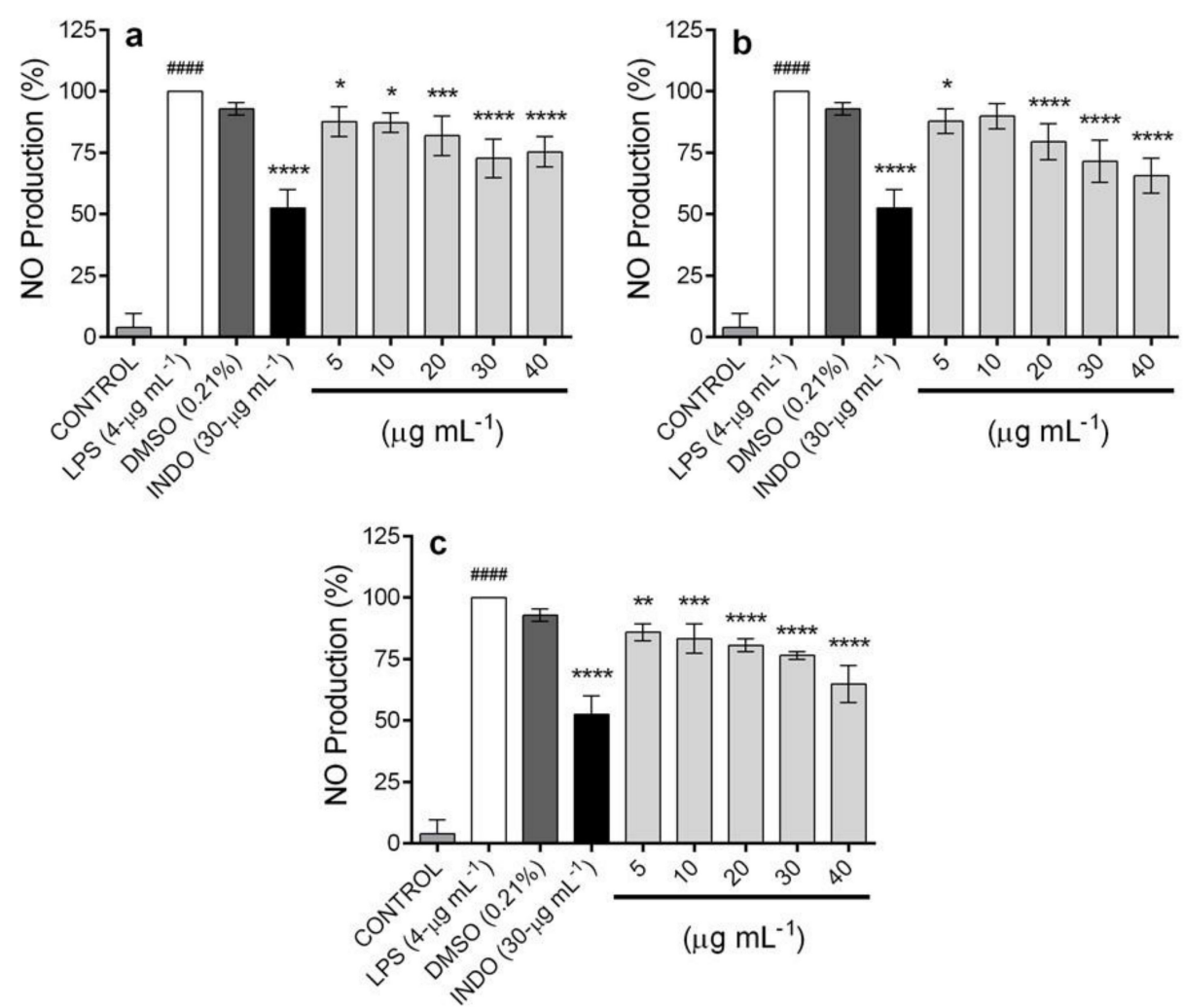

Figure 8. Effect of ethyl acetate extracts from A. pinchichensis cell suspension cultures on the nitric oxide (NO) production in lipopolysaccharide (LPS)-stimulated RAW 264.7 macrophages. (a) extract from day 8 (D8); (b) extract from day 12 (D12); (c) extract from day 16 (D16). The values are expressed as the mean \pm SD of three independent experiments $(n=3)$. Significance was determined using ANOVA followed by Dunnett's multiple comparisons test (\#\#\#p <0.0001 LPS compared with the control group; ${ }^{*} p<0.05$ and ${ }^{* *} p<0.0001$ DMSO, INDO (indomethacin), and extracts compared with the LPS group).

The results showed that D12 and D16 were the most active extracts that inhibited NO production at $40-\mu \mathrm{g} \mathrm{mL} \mathrm{m}^{-1}$, with $35.14 \% \pm 7.55 \%$ and $34.42 \% \pm 7.15 \%$ inhibition, respectively. On the other hand, the extract from D showed $24.69 \% \pm 6.17 \%$ inhibition in NO production; at this point of the kinetics, compound 2 is produced in greater quantity compared to compound $3\left(510.75 \pm 29.10-\mu \mathrm{g} \mathrm{g}^{-1} \mathrm{DW}\right.$ and $127.85 \pm 14.86-\mu \mathrm{g} \mathrm{g}^{-1} \mathrm{DW}$, respectively). In the extract from D12, the concentrations of the compounds were $434.01 \pm 32.25-\mu \mathrm{g} \mathrm{g}^{-1} \mathrm{DW}(2)$ and $244.89 \pm 13.34-\mu \mathrm{g} \mathrm{g}^{-1} \mathrm{DW}$ (3); finally, it was observed that the extract from D16 contains more of compound $3\left(410.60 \pm 36.91-\mu \mathrm{g} \mathrm{g}^{-1} \mathrm{DW}\right)$, which showed a greater effect with respect to compound 2, which was identified at $335.45 \pm 21.72-\mu \mathrm{g} \mathrm{g}{ }^{-1} \mathrm{DW}$. This result corroborates the outstanding effect of compound 3: as it increases in content in the extracts, the anti-inflammatory effect also increases proportionally. However, in a pure way, both compounds have an important anti-inflammatory effect. Indomethacin (the positive control) showed an inhibition of $47.45 \% \pm 7.41 \%$ at $30-\mu \mathrm{gL}^{-1}$ (Figure 8 ).

The results obtained in this work are of great interest, because (2S,3R)-5-acetyl-7,3 $\alpha$-dihydroxy-2 $\beta$-(1-isopropenyl)-2,3-dihydrobenzofuran (2) and 3-epilupeol (3) have important pharmacological properties. Compound 2 inhibits the secretion of NO, interleukin (IL)-6, and tumor necrosis factor-alpha (TNF- $\alpha$ ) in RAW 264.7 macrophages, as well as the activation of nuclear factor-kappa beta (NF-kB) in RAW-blue macrophages [27], while compound 3 shows antiviral [50], anti-inflammatory [51], antitubercular [52], and cytotoxic activity [53]. As to the anti-inflammatory activity, 
3-epilupeol (3) shows a marked inhibition of the edema induced by 12-O-tetradecanoylphorbol-13-acetate(TPA) in mice and exhibits nitric oxide (NO) production inhibitory activity in LPS-activated macrophages [54-57]. Nitric oxide (NO) is a short-lived bioactive molecule that plays an important role in the host defense response against various pathogens, such as bacteria, viruses, fungi, and parasites, and, also, participates in pathophysiological processes such as neuronal communication, vasodilatation, and neurotoxicity [58,59].

The importance of the anti-inflammatory effects of 3-epilupeol (3) lies in the fact that the excessive production of $\mathrm{NO}$ causes tissue damage, extensive systemic vasodilatation, and hypotension [54]. In addition, $\mathrm{NO}$ is involved in inflammatory disorders, including bowel diseases, rheumatoid arthritis, chronic hepatitis, pulmonary fibrosis, and colon cancer [56,58-60].

\section{Materials and Methods}

\subsection{General Procedures}

Compounds 1-7 were isolated by column chromatography (silica gel 70-230 mesh; Merck, Darmstadt, Germany), and the purity of the compounds was checked by gas chromatography coupled with mass spectrometry (GC-MS); detection was performed at ultraviolet (UV) light (366 and $254 \mathrm{~nm}$ ) and after spraying with $\mathrm{Ce}\left(\mathrm{SO}_{4}\right)_{2} 2\left(\mathrm{NH}_{4}\right) 2 \mathrm{SO}_{4} 2 \mathrm{H}_{2} \mathrm{O}$ (Sigma-Aldrich, Inc., Toluca, State of México, Mexico), followed by heating. The ${ }^{1} \mathrm{H}$ - and ${ }^{13} \mathrm{C}-;$ DEPT; and 2D nuclear magnetic resonance (NMR) (correlated spectroscopy (COSY), heteronuclear single quantum correlation (HSQC), and heteronuclear multiple bond correlation (HMBC)) experiments were recorded on a Varian Unity Inova $200 \mathrm{MHz}$ and a Bruker AVANCE IIIHD 500 at $500 \mathrm{MHz}$, using $\mathrm{CDCl}_{3}$ and $\mathrm{CD}_{3} \mathrm{OD}$ with tetramethylsilane (TMS) as the internal standard. Optical rotations were measured on a 241 digital polarimeter at $25^{\circ} \mathrm{C}$ (Perkin Elmer, Waltham, MA, USA), equipped with a sodium lamp (589 nm) and microcell. Indomethacin (indo), dimethyl sulfoxide (DMSO), etoposide, lipopolysaccharide (LPS) from Escherichia coli serotype 055: B5, sodium nitrite $\left(\mathrm{NaNO}_{2}\right)$, phosphoric acid $\left(\mathrm{H}_{3} \mathrm{PO}_{4}\right), \mathrm{N}-(1$-naphtyl) ethylenediamine dihydrochloride, and sulfanilamide were purchased from Sigma-Aldrich. DMEM/F12 (Dulbecco's modified Eagle's medium/Nutrient Mixture F-12) and fetal bovine serum (FBS) were from GIBCO (Waltham, MA, USA). (3-(4,5-dimethyl-2-yl)-5-(3-carboxymethoxyphenyl)-2-(4-sulfophenyl)-2H-tetrazolium, inner salt; MTS) was from Promega Co. (Fitchburg, WI, USA). Murine macrophage cell line RAW 264.7 (Tib-71 ${ }^{\mathrm{TM}}$ ) was from ATCC $®$ (Washington, DC, USA). Compounds 8-15 were identified by GC-MS. Compounds 2 and 3 were quantitated by GC-MS using a calibration curve of authentic samples following the method described for the A. pichinchensis callus culture [27].

\subsection{Plant Material}

Plants and seeds of Ageratina pichinchensis (Kunth) were collected in Tepoztlán Morelos, Mexico in March 2018 (1900'43.88” N, 99.05'38.66" W), identified by Gabriel Flores Franco, and deposited at the HUMO Herbarium of the Universidad Autónoma del Estado de Morelos (UAEM), with the voucher number 33913.

\subsection{Establishment of Cell Suspension Cultures}

Friable callus cultures of A. pichinchensis were previously established by our working group [27]. Calluses were subcultured in the same Murashige and Skoog (MS) semisolid culture medium containing $3 \%$ sucrose, $1.0-\mathrm{mg} \mathrm{L}^{-1} \alpha$-naphthaleneacetic acid (NAA), and 0.1- $\mathrm{mg} \mathrm{L}^{-1} 6$-furfurylaminopurine (KIN). The 20-day-old calluses were used to establish the cell suspension cultures. Fresh calluses (5 g) were transferred to 250-mL Erlenmeyer flasks containing $50 \mathrm{~mL}$ of MS liquid culture medium using the same conditions and plant growth regulator as in the callus cultures. Cell suspension cultures were placed on an orbital shaker at $110 \mathrm{rpm}$ and incubated at $25 \pm 2{ }^{\circ} \mathrm{C}$ under a photoperiod of 16 -h with white fluorescent light $\left(50-\mu \mathrm{mol} \mathrm{m} \mathrm{m} \mathrm{s}^{-1}\right)$. When an increase of biomass was shown in the flasks, cells were harvested and screened with 200- $\mu$ m nylon mesh filters (Whatman No. 1) to obtain a homogeneous 
cell culture. To increase the biomass, the cells were subcultured every 15 days for six months using an inoculum size of $10 \%(\mathrm{v} / \mathrm{v})$ in 500-mL Erlenmeyer flasks with $100 \mathrm{~mL}$ of liquid culture medium.

\subsubsection{Growth Kinetics}

The growth kinetics of the cell suspension culture was carried out in 250-mL flasks without modifying the composition of the culture medium. Each flask containing $50 \mathrm{~mL}$ of medium MS was inoculated with $2 \mathrm{~g}$ of fresh cells and incubated in the same conditions mentioned above. Three flasks were harvested every two days, and the culture was allowed to grow for 22 days. Harvested cells were washed with distilled water, filtered with a cellulose filter (Whatman No. 1), and dried in an oven at $55{ }^{\circ} \mathrm{C}$ for $24 \mathrm{~h}$. Then, dry-weight biomass (DW) data were recorded to perform the culture growth curve. The specific cell growth rate $(\mu)$ was calculated by plotting the natural logarithm of the cell growth data versus time. The doubling time (Dt) was computed from the $\mu$ exponential data.

\subsubsection{Cell Viability}

The cell viability of the cell suspension culture was measured by Evan's blue day exclusion method [61]. A sample of $1 \mathrm{~mL}$ of cell suspension was taken from each flask and incubated into $0.25 \%$ Evan's blue stain for $5 \mathrm{~min}$, and at least 700 cells were counted. Viable cells were considered those that were not stained. All the experiments were repeated three times, with three replicates each.

\subsubsection{Sugar Quantification and $\mathrm{pH}$ Measurement}

During each sampling of growth kinetics, 5-mL aliquots from the residual culture medium of each biomass sample were taken; their $\mathrm{pH}$ was measured with a potentiometer (Science Med SM-25CW) and total sugar content by the phenol-sulfuric method [62]. A calibration curve was performed using sucrose as a standard at concentrations of 0.1 to $1.0-\mu \mathrm{g} \mathrm{mL}^{-1}$. A sample aliquot $(2 \mathrm{~mL})$ of the sample was mixed with $2 \mathrm{~mL}$ of phenol reagent at $5 \%$ in digester tubes and placed in a rack submerged in a cold-water bath. Then, $5 \mathrm{~mL}$ of $\mathrm{H}_{2} \mathrm{SO}_{4}$ concentrated was added to the mixture and allowed to stand for $15 \mathrm{~min}$ and analyzed in a spectrophotometer at $490 \mathrm{~nm}$ against a blank.

\subsection{Extraction and Isolation of Compounds from Cell Suspension Cultures}

Biomass harvested on day 20 was dried in an oven at $40{ }^{\circ} \mathrm{C}(12.30 \mathrm{~g})$ and extracted with $100 \mathrm{~mL}$ of ethyl acetate by sonication ( $30 \mathrm{~min}$ ); the extraction process was performed in triplicate. The excess of solvent was eliminated in a rotatory evaporator under reduced pressure, and a brown residue $(1.3 \mathrm{~g})$ was obtained. A second extraction was carried out with methanol $(3 \times 100 \mathrm{~mL})$; the solvent was removed by distillation, giving rise to a resinous residue $(2.4 \mathrm{~g})$.

The ethyl acetate extract (1.2 g) was fractioned in an open chromatographic column previously packed with silica gel ( $36 \mathrm{~g}, 70-230$ mesh, Merck) and eluted with a $n$-hexane, ethyl acetate gradient system (100:00, 95:05, 90:10, 85:15, 80:20, 75:25, and 00:00) v/v). Fractions of $20 \mathrm{~mL}$ were collected to obtain 64 fractions that were monitored by thin-layer chromatography (TLC) (ALUGRAM@SIL G/UV254 silica gel plates). Fractions that showed TLC similarity were grouped, obtaining six groups: MSR-EA-1 (1-9; $241.4 \mathrm{mg})$, MSR-EA-2 (10-18; $138.4 \mathrm{mg})$, MSR-EA-3 (19-32; $122.3 \mathrm{mg}$ ), MSR-EA-4 (33-42; $147.2 \mathrm{mg}$ ), MSR-EA-5 (43-55; $216.5 \mathrm{mg}$ ), and MSR-EA-6 (56-64; $270.6 \mathrm{mg}$ ). The MSR-EA-1 fraction showed a single spot in TLC, and its GC-MS analysis indicated that this fraction consisted of a mixture of palmitic acid (12), hexadecenoic acid methyl ester (13), and isopropyl palmitate (14). The MSR-EA-2 fraction (120 mg), obtained in an $n$-hexane/ethyl acetate system (95:05), was purified using column chromatography, silica gel (4 g), and an $n$-hexane/ethyl acetate gradient system (98:02 $\rightarrow$ 86: 14). In total, 28 fractions of $3 \mathrm{~mL}$ each were obtained; in fractions $16-22$, obtained in a $n$-hexane/ethyl acetate system (92:08), a single spot was observed in TLC, and these were combined to obtain $18.3 \mathrm{mg}(0.1 \%)$ of a colorless oil. Analysis of ${ }^{1} \mathrm{H}$ and ${ }^{13} \mathrm{C}-\mathrm{NMR}$ data allowed us to identify desmethoxyencecalin (1). The MSR-EA-3 fraction (120 mg) was purified by column chromatography, silica gel, and a system of gradients with $n$-hexane/ethyl acetate (96:04 $\rightarrow$ 80:20). From this purification 
process, 53 fractions were obtained. The mixture of stigmasterol (4) and $\beta$-sitosterol (5) (41.8 mg; $0.3 \%)$ was obtained as a white amorphous solid in the fractions $42-48$, eluted with $n$-hexane/ethyl acetate (87:13). An aliquot (115 mg) of the MSR-EA-4 group was purified by column chromatography. Silica gel was used as the stationary phase, and a $n$-hexane/ethyl acetate gradient system $(90: 10 \rightarrow 80: 20)$ was used as the mobile phase. Forty-eight fractions were obtained, and the purification process was monitored by TLC, which allowed us to create five groups of fractions (MSR-EA-4A to MSR-EA-4E). In the MSR-EA-4B (10.3 mg) group obtained in the 86:14 system ( $n$-hexane/ethyl acetate), a mixture of sterols (4) and (5) was identified; from the group MSR-EA-4C (37.6 mg) obtained in 84:16 ( $n$-hexane/ethyl acetate), a crystalline solid was obtained. It was analyzed by ${ }^{1} \mathrm{H}$ and ${ }^{13} \mathrm{C}-\mathrm{NMR}$, and its data allowed us to identify it as 3-epilupeol (3). The MSR-EA-4D group ( $8 \mathrm{mg}$ ) obtained in an 82:18 system ( $n$-hexane/ethyl acetate) was analyzed by GC-MS, and the compounds 24-methylene-9,19-cyclolanastan-3 $\beta$-ol (8) and 24-methylenecycloartan-3-one (9) were identified. Column chromatographic purification of the MSR-EA-5 fraction (216.5 mg), using a n-hexane-EtOAc gradient system (95:05 $\rightarrow$ 70:30), provided 64 fractions. These were combined according to their chemical profiles observed in TLC in seven groups of fractions: MSR-EA-5A (1-20; $34.6 \mathrm{mg})$, MSR-EA-5B (21-25; $23.4 \mathrm{mg})$, MSR-EA-5C (26-33; 19.2 mg), MSR-EA-5D (34-42; $16.9 \mathrm{mg})$, MSR-EA-5E (43-50; $18.1 \mathrm{mg})$, MSR-EA-5F (51-58; $28.7 \mathrm{mg})$, and MSR-EA-5G (59-64; $44.2 \mathrm{mg})$. Fractions 51-58 eluted with 76:24 $n$-hexane-EtOAc contained a viscous liquid, and a single spot was observed on TLC. This was analyzed by ${ }^{1} \mathrm{H}$ and ${ }^{13} \mathrm{C}-\mathrm{NMR}$, and the analysis of their data led to the identification of the compound as (2S,3R)-5-acetyl-7,3 $\alpha$-dihydroxy-2 $\beta$-(1-isopropenyl)-2,3-dihydrobenzofuran (2).

\subsubsection{Desmethoxyencecalin (1)}

Compound (1) was isolated as a colorless oil. ${ }^{1} \mathrm{H}-\mathrm{NMR}\left(200 \mathrm{MHz}, \mathrm{CDCl}_{3}\right) \delta: 7.69(1 \mathrm{H}, \mathrm{dd}, \mathrm{J}=8.5$, 2.2, Hz, H-7), $7.56(1 \mathrm{H}, \mathrm{d}, J=2.2 \mathrm{~Hz}, \mathrm{H}-5), 6.76(1 \mathrm{H}, \mathrm{d}, J=8.5 \mathrm{~Hz}, \mathrm{H}-8), 6.45(1 \mathrm{H}, \mathrm{d}, J=9.9 \mathrm{~Hz}, \mathrm{H}-4)$, $5.58(1 \mathrm{H}, \mathrm{d}, \mathrm{J}=10 \mathrm{~Hz}, \mathrm{H}-3), 2.47\left(3 \mathrm{H}, \mathrm{s}, \mathrm{CH}_{3}\right.$ of $\left.\mathrm{Ac}\right), 1.40\left(2 \mathrm{CH}_{3}, \mathrm{~s}, \mathrm{C}-11\right.$ and C-12). ${ }^{13} \mathrm{C}-\mathrm{NMR}(50 \mathrm{MHz}$, $\mathrm{CDCl}_{3}$ ) 196.54 (CO of Ac), 157.29 (C-10), 131.24 (C-6), 130.72 (C-7), 127.54 (C-5), 127.46 (C-3), 124.56 (C-4), 120.67 (C-9), 116.24 (C-8), 77.67 (C-2), $26.51\left(\mathrm{CH}_{3}, \mathrm{C}-14\right), 23.36\left(2 \mathrm{CH}_{3}, \mathrm{C}-11\right.$, and C-12)). These data match those in the literature [27]. Spectra of ${ }^{1} \mathrm{H}$ and ${ }^{13} \mathrm{C}-\mathrm{NMR}$ are in Figures S1 and S2.

\subsection{2. (2S,3R)-5-Acetyl-7,3 $\alpha$-dihydroxy-2 $\beta$-(1-isopropenyl)-2,3-dihydrobenzofuran (2)}

Compound (2) was isolated as a yellowish oil. ${ }^{1} \mathrm{H}-\mathrm{NMR}\left(200 \mathrm{MHz}, \mathrm{CDCl}_{3}\right) \delta: 7.53(1 \mathrm{H}, \mathrm{d}, J=1.4 \mathrm{~Hz}$, H-6), $7.44(1 \mathrm{H}, \mathrm{d}, J=1.4 \mathrm{~Hz}, \mathrm{H}-4), 5.13(1 \mathrm{H}, \mathrm{d}, J=3.8 \mathrm{~Hz}, \mathrm{H}-3), 5.03(1 \mathrm{H}, \mathrm{d}, J=1.2 \mathrm{~Hz}, \mathrm{H}-12 \mathrm{a}), 4.96(1 \mathrm{H}, \mathrm{d}$, $J=3.8 \mathrm{~Hz}, \mathrm{H}-2), 4.89(1 \mathrm{H}, \mathrm{d}, J=1.2 \mathrm{~Hz}, \mathrm{H}-12 \mathrm{~b}), 2.46$ (3H, s, H-14), 1.67 (3H, s, H-11). ${ }^{13} \mathrm{C}-\mathrm{NMR}(50 \mathrm{MHz}$, $\mathrm{CDCl}_{3}$ ): 197.36 (C-13), 151.89 (C-8), 140.92 (C-7), 140.67 (C-10), 132.37 (C-5), 129.33 (C-9), 118.85 (C-4), 117.91 (C-6), 113.54 (C-12), 95.78 (C-2), 76.88 (C-3), 26.69 (C-14), and 17.56 (C-11). These data match those in the literature [27]. Spectra of ${ }^{1} \mathrm{H}$ and ${ }^{13} \mathrm{C}$ NMR are in Figures S3 and S4.

\subsubsection{3-Epilupeol (3)}

Compound (3) was isolated as a crystalline solid. ${ }^{1} \mathrm{H}-\mathrm{NMR}\left(200 \mathrm{MHz}, \mathrm{CDCl}_{3}\right) \delta: 4.58(1 \mathrm{H}, \mathrm{d}$, $J=2.2 \mathrm{~Hz}, 29 \mathrm{a}) ; 4.56(1 \mathrm{H}, \mathrm{d}, J=1.2 \mathrm{~Hz}, 29 \mathrm{~b}) ; 3.26(1 \mathrm{H}, \mathrm{t}, J=2.8 \mathrm{~Hz}, \mathrm{H}-3) ; 2.19(1 \mathrm{H}, \mathrm{td}, J=11,5.9 \mathrm{~Hz}$, H-19); 1.88 (2H, c, H-21); 1.66 (2H, m, H-2); 1.65 (3H, s, H-30); 1.63 (2H, t, H-22); 1.52 (2H, m, H-16); 1.40 (1H, m, H-18); 1.42 (1H, m, H-5); 1.37 (2H, m, H-1, H-15); 1.36 (6H, m, H-7, H-11, H-12,); 1.34 (2H, m, H-6); 1.27 (1H, m, H-13); 1.19 (1H, t, H-9); 1.10 (6H, s, $\mathrm{CH}_{3}-23$ and 24); $0.98\left(3 \mathrm{H}, \mathrm{s}, \mathrm{CH}_{3}-25\right) ; 0.91(3 \mathrm{H}$, s, $\left.\mathrm{CH}_{3}-26\right) ; 0.82\left(3 \mathrm{H}, \mathrm{s}, \mathrm{CH}_{3}-28\right) ; 0.84\left(3 \mathrm{H}, \mathrm{s}, \mathrm{CH}_{3}-27\right) .{ }^{13} \mathrm{C}-\mathrm{NMR}\left(50 \mathrm{MHz}, \mathrm{CDCl}_{3}\right) \delta: 151.23(\mathrm{C}-20)$; 109.51 (C-29); 76.47 (C-3); 50.45 (C-9); 49.25 (C-5); 48.53 (C-18); 48.25 (C-19); 43.23 (C-17); 43.08 (C-14); 41.18 (C-8); 40.26 (C-22); 38.18 (C-13); 37.69 (C-4); 37.51 (C-10); 35.81 (C-16); 34.38 (C-7); 33.28 (C-1); 30.06 (C-21); 28.48 (C-23); 27.60 (C-15); 25.63 (C-2); 25.33 (C-12); 22.38 (C-24); 21.12 (C-11); 19.48 (C-30); 18.53 (C-6); 18.24 (C-28); 16.17 (C-25); 16.12 (C-26); and 14.92 (C-27). These data match those in the literature [27]. Spectra of ${ }^{1} \mathrm{H}$ and ${ }^{13} \mathrm{C}$ NMR are in Figures S5 and S6. 


\subsubsection{Stigmasterol (4) and $\beta$-Sitosterol (5)}

Compounds (4) and (5) were isolated as white amorphous solids. $\delta:{ }^{1} \mathrm{H}-\mathrm{NMR}\left(200 \mathrm{MHz}, \mathrm{CDCl}_{3}\right) \delta$ : $5.13(1 \mathrm{H}, \mathrm{t}, J=7.8 \mathrm{~Hz}, \mathrm{H}-6) ; 5.07$ (2H, m, H-22, H-23); 3.52 (2H, m, H-3); 1.62 to 1.95 (4H, m, H-7); 1.49 to 1.55 (2H, m, H-8); 0.85 to 0.93 ( $2 \mathrm{H}, \mathrm{m}, \mathrm{H}-9) ; 1.47$ to 1.55 (4H, m, H-11); 1.19 to 1.23 and 1.91 to 2.03 (4H, $\mathrm{m}, \mathrm{H}-12) ; 1.01$ to 1.17 (2H, m, H-14); 1.48 to 1.60 (2H, m, H-25); 0.85 to 1.85 ( $22 \mathrm{H}, \mathrm{m}, \mathrm{H}-15$ to H-24 and $\mathrm{H}-28) ; 0.92\left(\mathrm{CH}_{3}, \mathrm{~d}, \mathrm{~J}=7.2 \mathrm{~Hz}, \mathrm{H}-27\right) ; 0.94\left(\mathrm{CH}_{3}, \mathrm{~d}, J=6.8 \mathrm{~Hz}, \mathrm{H}-26\right) ; 0.98\left(\mathrm{CH}_{3}, \mathrm{~d}, J=6.4 \mathrm{~Hz}, \mathrm{H}-21\right)$; $0.87\left(\mathrm{CH}_{3}, \mathrm{~s}, \mathrm{H}-18\right) ; 1.09\left(\mathrm{CH}_{3}, \mathrm{~s}, \mathrm{H}-19\right) .{ }^{13} \mathrm{C}-\mathrm{NMR}\left(50 \mathrm{MHz}, \mathrm{CDCl}_{3}\right) \delta: 37.5\left(\mathrm{CH}_{2}, \mathrm{C}-1\right) ; 31.9\left(\mathrm{CH}_{2}, \mathrm{C}-2\right)$; 72.02 (CH, C-3); $40.45\left(\mathrm{CH}_{2}, \mathrm{C}-4\right) ; 140.76$ (C, C-5); $121.72(\mathrm{CH}, \mathrm{C}-6) ; 32.18\left(\mathrm{CH}_{2}, \mathrm{C}-7\right) ; 32.34(\mathrm{CH}, \mathrm{C}-8)$; 50.46 (CH, C-9); 36.38 (C, C-10); $21.43\left(\mathrm{CH}_{2}, \mathrm{C}-11\right) ; 39.86\left(\mathrm{CH}_{2}, \mathrm{C}-12\right) ; 42.74$ (C, C-13) 56.77 and 57.03 (CH, C-14); 24.32 and $24.61\left(\mathrm{CH}_{2}, \mathrm{C}-15\right) ; 28.25$ and $28.51\left(\mathrm{CH}_{2}, \mathrm{C}-16\right) ; 57.08(\mathrm{CH}, \mathrm{C}-17) ; 12.10\left(\mathrm{CH}_{3}, \mathrm{C}-18\right)$; $19.68\left(\mathrm{CH}_{3}, \mathrm{C}-19\right) ; 36.28$ and $40.14(\mathrm{CH}, \mathrm{C}-20) ; 18.21$ and $19.10\left(\mathrm{CH}_{3}, \mathrm{C}-21\right) ; 34.21$ and $138.76\left(\mathrm{CH}_{2}\right.$ and $\mathrm{CH}, \mathrm{C}-22) ; 26.38$ and $129.50\left(\mathrm{CH}_{2}\right.$ and $\left.\mathrm{CH}, \mathrm{C}-23\right) ; 46.07$ and $51.37(\mathrm{CH}, \mathrm{C} 24) ; 29.4(\mathrm{CH}, \mathrm{C}-25) ; 19.31$ and $2104\left(\mathrm{CH}_{3}, \mathrm{C}-26\right) ; 19.30$ and $19.23\left(\mathrm{CH}_{3}, \mathrm{C}-27\right) ; 23.02$ and $23.54\left(\mathrm{CH}_{2}, \mathrm{C}-28\right)$; and $12.26\left(\mathrm{CH}_{3}, \mathrm{C}-29\right)$. These data match those in the literature, and authentic samples are available in our laboratory [27].

$\mathrm{MeOH}$ extract ( $2.4 \mathrm{~g}$ ) was fractionated in an open chromatographic column previously packed with silica gel (72 g, 70-230 mesh; Merck) and eluted with a $\mathrm{CH}_{2} \mathrm{Cl}_{2}: \mathrm{MeOH}$ gradient system (100:00, 95:05, 90:10, 85:15, 80:20, 75:25, and 00:100, v/v). Fractions of $50 \mathrm{~mL}$ were collected to obtain 118 fractions and monitored by TLC. Fractions that showed similarity in the TLC analysis were grouped into five groups: MSR-M-1 (1-60; $548.3 \mathrm{mg})$, MSR-M-2 (61-83; $218.6 \mathrm{mg})$, MSR-M-3 (84-86; $314.8 \mathrm{mg})$, MSR-M-4 (87-95; $112.6 \mathrm{mg})$, and MSR-M-5 (96-118; $878.4 \mathrm{mg})$. The MSR-M-1 group was analyzed by GC-MS, and the compounds palmitamide (15), oleamide (16), and methyl pyroglutamate (17) were identified. By successive chromatography of the fraction MSR-M-2, using silica gel as the stationary phase and a system of gradients $(95: 05 \rightarrow 88: 12)$ with $n$-hexane/ethyl acetate, compound 1 (8 mg) was identified. Fractions 84-86 (MSR-M-3; $314.8 \mathrm{mg}$ ) were obtained in a gradient system of increasing polarity with $\mathrm{CH}_{2} \mathrm{Cl}_{2}$ : $\mathrm{MeOH}(90: 10 \rightarrow 85: 15)$; this fraction was purified by column chromatography, silica gel, and an $n$-hexane/ethyl acetate elution system $(90: 10 \rightarrow 80: 20)$. Of the fractions obtained in the $n$-hexane/ethyl acetate system (86:14), in the mixture of sterols, we identified 4 and $5(46.8 \mathrm{mg})$, and in the fractions obtained from the (82:18) system, compound 2 (6 mg) was obtained. The MSR-M-4 fraction $(112.6 \mathrm{mg})$ was purified by column chromatography and silica gel and eluted with a $\mathrm{CH}_{2} \mathrm{Cl}_{2}: \mathrm{MeOH}(98: 02 \rightarrow 70: 30)$ gradient system; 68 fractions were obtained. Fractions that showed TLC similarity were grouped into three groups: MSR-M-4A (1-32; 21.2 mg), MSR-M-4B (33-42; $32.7 \mathrm{mg})$, and MSR-M-4C (43-68; $48.4 \mathrm{mg})$. The MSR-M-4A group was analyzed by GC-MS, and compounds 24-metilene-9,19-cyclolanastan-3 $\beta$-ol (8) and 24-methylenecycloartan-3-one (9) were identified. The MSR-M-4B fraction (32.2 mg) obtained in a $\mathrm{CH}_{2} \mathrm{Cl}_{2} / \mathrm{MeOH}$ system $(88: 12 \rightarrow 82: 18)$ was purified by column chromatography, silica gel, and an isocratic system with $\mathrm{CH}_{2} \mathrm{Cl}_{2} / \mathrm{MeOH}$ (84:16), obtaining a semisolid (14 mg). Analysis by ${ }^{1} \mathrm{H}$ and ${ }^{13} \mathrm{C}-\mathrm{NMR}$ allowed the compound to be identified as (-)-Artemesinol (6). The MSR-M-4C fraction (48.4 mg) obtained in a $\mathrm{CH}_{2} \mathrm{Cl}_{2} / \mathrm{MeOH}$ system $(80: 20 \rightarrow 74: 26)$ was purified by column chromatography, silica gel, and an isocratic system with $\mathrm{CH}_{2} \mathrm{Cl}_{2} / \mathrm{MeOH}(75: 25)$, obtaining a semisolid (34 mg). Analysis of NMR in $1 \mathrm{D}\left({ }^{1} \mathrm{H}\right.$ and $\left.{ }^{13} \mathrm{C}\right)$ and $2 \mathrm{D}$ (COSY, HSQC, and HMBC) allowed the compound to be identified as (-)-Artemesinol glucoside (7).

\subsection{5. (-)-Artemesinol (6)}

Compound (6) was isolated as a semi-solid mass. ${ }^{1} \mathrm{H}$ NMR $\left(200 \mathrm{MHz}, \mathrm{CDCl}_{3}: \mathrm{CD}_{3} \mathrm{OD}\right) \delta 7.65$ $(1 \mathrm{H}, \mathrm{dd}, J=8.4,2.2 \mathrm{~Hz}, \mathrm{H}-7), 7.51(1 \mathrm{H}, \mathrm{d}, J=2.2 \mathrm{~Hz}, \mathrm{H}-5), 6.73(1 \mathrm{H}, \mathrm{d}, J=8.5 \mathrm{~Hz}, \mathrm{H}-8), 6.40(1 \mathrm{H}, \mathrm{d}$, $J=10 \mathrm{~Hz}, \mathrm{H}-4), 5.58(1 \mathrm{H}, \mathrm{d}, J=10 \mathrm{~Hz}, \mathrm{H}-3), 3.53\left(2 \mathrm{H}, \mathrm{s}, \mathrm{CH}_{2}-14\right), 2.44\left(3 \mathrm{H}, \mathrm{s}, \mathrm{CH}_{3}-12\right)$, and $1.3(3 \mathrm{H}, \mathrm{s}$, $\left.\mathrm{CH}_{3}-\mathrm{C}-\mathrm{O}\right) .{ }^{13} \mathrm{C}$ NMR $\left(50 \mathrm{MHz}, \mathrm{CDCl}_{3}: \mathrm{CD}_{3} \mathrm{OD}\right) \delta 196.84$ (C-11), 157.38 (C-9), 130.21 (C-6), 127.94 (C-7), 130.97 (C-3), 127.45 (C-5), 116.67 (C-4), 120.64 (C-10), 124.32 (C-8), 80.86 (C-2), 68.99 (C-14), 26.32 (C-12), and 23.49 (C-13). Spectra of ${ }^{1} \mathrm{H}$ and ${ }^{13} \mathrm{C}$ NMR are in Figures S7 and S8. Stereochemistry at C-2 was not determined, but a relative $(R)$ configuration was suggested, compared to the optical rotation $(\alpha)_{D}=-4.5^{\circ}\left(\mathrm{c} 0.89, \mathrm{CHCl}_{3}\right)$ reported for this compound [39]. 


\subsection{6. ( \pm )-Artemesinol Glucoside (7)}

Compound (7) was isolated as a semisolid mass. ${ }^{1} \mathrm{H}$ NMR $\left(500 \mathrm{MHz}, \mathrm{CDCl}_{3}: \mathrm{CD}_{3} \mathrm{OD}\right) \delta 7.69(1 \mathrm{H}$, $\mathrm{dd}, J=8.4,2.2 \mathrm{~Hz}, \mathrm{H}-7), 7.56(1 \mathrm{H}, \mathrm{d}, J=2.2 \mathrm{~Hz}, \mathrm{H}-5), 6.77(1 \mathrm{H}, \mathrm{d}, J=8.5 \mathrm{~Hz}, \mathrm{H}-8), 6.42(1 \mathrm{H}, \mathrm{d}, J=10 \mathrm{~Hz}$, H-4), $5.67(1 \mathrm{H}, \mathrm{d}, J=10 \mathrm{~Hz}, \mathrm{H}-3), 4.46\left(1 \mathrm{H}, \mathrm{d}, J=7.8 \mathrm{~Hz}, \mathrm{H}-1^{\prime}\right), 3.91(1 \mathrm{H}, \mathrm{d}, J=10.6 \mathrm{~Hz}, \mathrm{H}-14 \mathrm{a})$, 3.87-3.18 (6H, m, H-2' to H-6'), $3.58(1 \mathrm{H}, \mathrm{d}, J=10.7 \mathrm{~Hz}, \mathrm{H}-14 \mathrm{~b}), 2.48\left(3 \mathrm{H}, \mathrm{s}, \mathrm{CH}_{3}-12\right)$, and $1.39(3 \mathrm{H}$, $\left.\mathrm{s}, \mathrm{CH}_{3}-13\right)$. The ${ }^{1} \mathrm{H}$ NMR data were compared with those reported [41]. ${ }^{13} \mathrm{C}$ NMR $(126 \mathrm{MHz}$, $\left.\mathrm{CDCl}_{3}: \mathrm{CD}_{3} \mathrm{OD}\right) \delta 197.44$ (C-11), 157.31 (C-9), 130.71 (C-6), 130.66 (C-7), 127.77 (C-3), 127.30 (C-5), 123.71 (C-4), 120.69 (C-10), 116.12 (C-8), 103.57 (C-1'), 79.55 (C-2), 76.18 (C-5'), 75.90 (C-3'), 75.19 (C-14), 73.51 (C-2'), 69.85 (C-4'), 62.19 (C-6'), 26.39 (C-12), and 23.79 (C-13). Spectra of 1H, 13C, COSY, DEPT, HSQC, and HMBC are in Figures S9-S14.

Compounds 8 and 9 and 12-17 were identified by comparing the GC relative retention times and MS fragmentation pattern of a single compound with those from the NIST 1.7a mass spectral library. GC-MS chromatograms of compounds 8 and 9 and 12-17 are in Figures S15-S17. Compounds 10 and 11 were identified in the suspension cells by comparing their GC relative retention times and MS fragmentation patterns. The standards used in the analysis were as follows: encecalin (10) and 3,5-diprenyl-4-hydroxyacetophenone (11), previously isolated from A. pichinchensis. GC-MS chromatograms are in Figure S18.

\subsection{Quantification of Compounds 2 and 3 by GC-MS}

Biomass collected at $0,2,4,6,8,10,12,14,16,18,20$, and 22 days were dried in an oven at $55^{\circ} \mathrm{C}$ for $24 \mathrm{~h}$. Subsequently, each sample was extracted by sonication with EtOAc $(25 \mathrm{~mL} \times 3)$ and $\mathrm{MeOH}$ $(25 \mathrm{~mL} \times 3)$ and concentrated in a rotatory evaporator. Maximum production of compounds 2 and 3 was identified in ethyl acetate extracts on days 8 (D8) and 16 (D16), respectively. For the quantitative analysis, a standard curve of compounds 2 and 3 was prepared in triplicate and analyzed by GC-MS. Concentrations of $2.2,1.1,0.55,0.275,0.1375$, and $0.06875-\mathrm{mg} \mathrm{mL}^{-1}$ were used for compound 2 and of $0.350,0.175,0.0875,0.04375$, and $0.02187-\mathrm{mg} \mathrm{mL}^{-1}$ for compound 3. Each standard solution was analyzed in triplicate to calculate the peak area ratio (y) and relative concentration (x); these data were used to construct a linear calibration curve, which showed acceptable linearity with correlation coefficients $r^{2}=0.9926$ and 0.9997 , respectively (Figures S9 and S10). The quantification of compounds 2 and 3 in the extracts was expressed as $\mu \mathrm{g} \mathrm{g}^{-1}$ biomass dry weight $\left(\mu \mathrm{g} \mathrm{g}^{-1} \mathrm{DW}\right)$.

\subsection{In Vitro Anti-Inflammatory Activity}

\subsubsection{Cell Culture}

RAW 264.7 cells were maintained in DMEM/F12 medium supplemented with 10\% heat-inactivated FBS, without antibiotics. Cells were cultured at $37^{\circ} \mathrm{C}$ in a humidified atmosphere containing $5 \% \mathrm{CO}_{2}$ and subcultured by scraping and seeding them in $25-\mathrm{cm}^{2}$ flasks of $96-$ well plates [52,53].

\subsubsection{Assay for Cell Viability}

Cells $\left(1 \times 10^{4}\right.$ cells/well in $100 \mu \mathrm{L}$ of medium) were seeded in a 96-well plate and incubated for $24 \mathrm{~h}$. Then, the cells were incubated for $22 \mathrm{~h}$ in the presence of extracts at various concentrations $\left(5-40 \mu \mathrm{g} \mathrm{mL}{ }^{-1}\right.$ ) or vehicle (DMSO, $0.21 \%$, v/v) or etoposide $\left(40-\mu \mathrm{g} \mathrm{mL} \mathrm{m}^{-1}\right.$ ), which served as a positive control, and cells without treatment were considered a negative control. Cell viability was determined by adding MTS solution to each well and incubating the cells for another $2 \mathrm{~h}$. The optical density was measured at $490 \mathrm{~nm}$ on a microplate reader.

\subsubsection{Treatment with LPS}

Cells $\left(2 \times 10^{4}\right.$ cells/well in $200 \mu \mathrm{L}$ of medium) were plated and incubated for $24 \mathrm{~h}$ in 96 -well plates. After that, the cells were incubated for $1 \mathrm{~h}$ in the presence of extracts at noncytotoxic concentrations 
(5 to $40-\mu \mathrm{g} \mathrm{mL}^{-1}$ ), a vehicle (DMSO, $0.21 \%, \mathrm{v} / \mathrm{v}$ ), or indomethacin $\left(30-\mu \mathrm{g} \mathrm{mL} \mathrm{L}^{-1}\right.$ ), which served as a positive control; cells without treatment were considered a negative control. Then, the cells were incubated at $37^{\circ} \mathrm{C}$ for $20 \mathrm{~h}$ with LPS at $4-\mu \mathrm{g} \mathrm{mL} \mathrm{m}^{-1}$ (for wells with extracts, vehicle, indomethacin, and $100 \%$ stimulus control) as a proinflammatory stimulus and without LPS (negative control). Finally, cell-free supernatants were collected and used for NO quantification.

\subsubsection{Determination of NO Concentration}

Nitrite, the stable end product of NO, was used as an indicator of NO production in the cell-free supernatants and was measured according to the Griess reaction. Briefly, $50 \mu \mathrm{L}$ of each supernatant were mixed with $100 \mu \mathrm{L}$ of Griess reagent (50 $\mu \mathrm{L}$ of $1.0 \%$ sulfanilamide and $50 \mu \mathrm{L}$ of $0.1 \%$ $\mathrm{N}$-(1-naphtyl)ethylenediamine dihydrochloride in $2.5 \%$ phosphoric acid solution) in a new 96 -well plate and incubated for $10 \mathrm{~min}$ at room temperature. The optical density at $540 \mathrm{~nm}\left(\mathrm{OD}_{540}\right)$ was measured with a microplate reader, and the nitrite concentrations in the samples were calculated by comparison with the $\mathrm{OD}_{540}$ of a standard curve of $\mathrm{NaNO}_{2}$ in a fresh culture medium $[27,57,60]$.

\subsection{Statistical Analysis}

The results shown were obtained from at least three independent experiments and are presented as the means \pm standard deviation. Statistical analysis was performed by one-way analysis of variance (ANOVA), followed by Dunnett's multiple comparisons test. For suspension cell cultures, the values of each experiment are means, and the bars represent the standard error of triplicate determinations. All statistical analyses were performed using GraphPad Prism®version 8.0 software; $p$-values $<0.5$ were

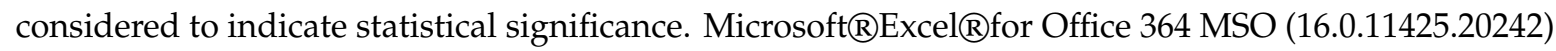
32-bit software was used for analysis.

\section{Conclusions}

The establishment of a cell suspension culture of $A$. pichinchensis is reported for the first time. This cell suspension culture retained the ability to produce the anti-inflammatory compounds 2,3-dihydrobenzofuran (2) and 3-epilupeol (3) identified previously in a callus culture from this species. Moreover, the yield of both compounds was improved, and the production time was reduced by almost half compared with callus cultures. Phytochemical analysis of the cell cultures led to the identification of 17 bioactive components, of which compounds $2-5$ and 8-11 were previously described to have anti-inflammatory, antimicrobial, antifungal, and gastroprotective properties. Furthermore, the in vitro anti-inflammatory efficacy of the cell culture extracts and the identification for the first time of (-)-Artemesinol (6), (-)-Artemesinol glucoside (7), encecalin (10), and 3,5-diprenyl-acetophenone (11) in cell cultures of $A$. pichinchensis offer a biotechnological tool for bioreactor scale-up to produce anti-inflammatory compounds in a sustainable way.

Supplementary Materials: The following are available online at http://www.mdpi.com/2223-7747/9/10/1398/s1: Figure S1: ${ }^{1} \mathrm{H}-\mathrm{NMR}$ spectrum $\left(200 \mathrm{MHz}, \mathrm{CDCl}_{3}\right)$ of desmethoxyencecalin (1), Figure S2: ${ }^{13} \mathrm{C}-\mathrm{DEPT}-\mathrm{NMR}$ spectrum $\left(50 \mathrm{MHz}, \mathrm{CDCl}_{3}\right)$ of desmethoxyencecalin (1), Figure S3: ${ }^{1} \mathrm{H}-\mathrm{NMR}$ spectrum $\left(200 \mathrm{MHz}, \mathrm{CDCl}_{3}: \mathrm{CD}_{3} \mathrm{OD}\right)$ of (2S,3R)-5-acetyl-7,3 $\alpha$-dihydroxy-2 $\beta$-(1-isopropenyl)-2,3-dihydrobenzofuran (2), Figure S4: ${ }^{13} \mathrm{C}$-NMR spectrum (50 MHz, $\left.\mathrm{CDCl}_{3}: \mathrm{CD}_{3} \mathrm{OD}\right)$ of (2S,3R)-5-acetyl-7,3 $\alpha$-dihydroxy-2 $\beta$-(1-isopropenyl)-2,3-dihydrobenzofuran (2), Figure S5: ${ }^{1} \mathrm{H}-\mathrm{NMR}$ spectrum $\left(200 \mathrm{MHz}, \mathrm{CDCl}_{3}\right)$ of 3-Epilupeol (3), Figure S6: ${ }^{13} \mathrm{C}-\mathrm{NMR}$ spectrum $\left(50 \mathrm{MHz}, \mathrm{CDCl}_{3}\right)$ of 3-Epilupeol (3), Figure S7: ${ }^{1} \mathrm{H}-\mathrm{NMR}\left(200 \mathrm{MHz}, \mathrm{CDCl}_{3}: \mathrm{CD}_{3} \mathrm{OD}\right)$ of (-)-Artemesinol (6), Figure S8: ${ }^{13} \mathrm{C}-\mathrm{NMR}$ (50 MHz, $\mathrm{CDCl}_{3}: \mathrm{CD}_{3} \mathrm{OD}$ ) of (-)-Artemesinol (6), Figure S9: ${ }^{1} \mathrm{H}-\mathrm{NMR}$ spectrum $\left(500 \mathrm{MHz}, \mathrm{CDCl}_{3}: \mathrm{CD}_{3} \mathrm{OD}\right)$ of (-)-Artemesinol glucoside (7), Figure S10: ${ }^{13} \mathrm{C}-\mathrm{NMR}$ spectrum $\left(125 \mathrm{MHz}, \mathrm{CDCl}_{3}: \mathrm{CD}_{3} \mathrm{OD}\right)$ of (-)-Artemesinol glucoside (7), Figure S11: DEPT spectrum $\left(125 \mathrm{MHz}, \mathrm{CDCl}_{3}: \mathrm{CD}_{3} \mathrm{OD}\right)$ of (-)-Artemesinol glucoside (7), Figure S12: COSY spectrum (500 MHz, CDCl $: \mathrm{CD}_{3} \mathrm{OD}$ ) of (-)-Artemesinol glucoside (7), Figure S13: HSQC spectrum $\left(500 \mathrm{MHz}, \mathrm{CDCl}_{3}: \mathrm{CD}_{3} \mathrm{OD}\right)$ of (-)-Artemesinol glucoside (7), Figure S14: $\mathrm{HMBC}$ spectrum (500 $\mathrm{MHz}_{2} \mathrm{CDCl}_{3}$ : $\mathrm{CD}_{3} \mathrm{OD}$ ) of (-)-Artemesinol glucoside (7), Figure S15a: GC-MS chromatogram of cell suspension culture extract with compounds 8 and 9, Figure S15b: Mass spectrum of compound 8, Figure S15: Mass spectrum of compound 9, Figure S16: GC-MS chromatogram of cell suspension culture extract with compounds 12-14, Figure S16b: Mass spectrum of compound 12, Figure S16c: Mass spectrum of compound 13, Figure S16d: Mass spectrum 
of compound 14, Figure S17a: GC-MS chromatogram of cell suspension culture extract with compounds 15-17, Figure S17b: Mass spectrum of compound 15, Figure S17c: Mass spectrum of compound 16, Figure S17d: Mass spectrum of compound 17, Figure S18a: GC-MS chromatogram of compounds 10-11 obtained of the ethyl acetate extract from wild plant $A$. pichinchensis, Figure S18b: GC-MS chromatograms of compound 10, Figure S18c: GC-MS chromatograms of compound 11, Figure S18d: GC-MS chromatograms of the compounds encecalin (10) and 3,5-diprenyl-4-hydroxyacetophenone (11) obtained of the ethyl acetate extract from A. pichinchensis cell suspension cultures, Figure S18e: GC-MS chromatogram of compound 10 obtained from acetate ethyl extract of cell suspension cultures, Figure S18f: GC-MS chromatogram of compound 11 obtained from acetate ethyl extract of cell suspension cultures, Figure S19: GC-MS chromatograms of standard compound and EtOAc extract. (a) 2,3-dihydrobenzofuran (2) profile used as a standard; (b) EtOAc extract profile from A. pichinchensis cell suspension culture at 8 days of culture showing the peak of 2,3-dihydrobenzofuran (2) compound, Figure S20: GC-MS chromatograms of standard compound and EtOAc extract. (a) 3-epilupeol (3) profile used as a standard; (b) EtOAc extract profile from A. pichinchensis cell suspension culture at 16 days of culture showing the peak of 3-epilupeol (3) compound.

Author Contributions: Conceptualization, F.C.-S. and S.M.-B.; formal analysis, A.R.-E.; funding acquisition, F.C.-S., S.M.-B., and L.A.; investigation, M.S.-R. and A.B.-A.; methodology, A.R.-E., A.B.-A, F.C.-S., S.M.-B., and L.A.; resources, F.C.-S., A.R.-E., and L.A.; supervision, S.M.-B.; writing-original draft, M.S.-R; and writing-review and editing, F.C.-S. and S.M.-B. All authors have read and agreed to the published version of the manuscript.

Funding: This research received no external funding.

Acknowledgments: MSR is grateful to PRODEP for providing fellowship 14513415. The authors thank Laboratorio Nacional de Estructura de Macromoléculas (Conacyt 279905) for the use of NMR and gas chromatography coupled with mass spectrometry and Maria Gregoria Medina Pintor (Centro de Investigaciones Químicas, UAEM) for skillful technical assistance in the analysis and GC/MS experiments.

Conflicts of Interest: The authors declare no conflict of interest.

\section{References}

1. Bremer, K. Asteraceae. In Cladistics and Classification, 1st ed.; Timber Press: Portland, OR, USA, $1994 ;$ p. 752.

2. Katinas, L.; Gutierrez, D.G.; Grossi, M.A.; Crisci, J.V. Panorama de la familia Asteraceae (Compositae) en la República Argentina. Bol. Soc. Argent. Bot. 2007, 42, 113-129.

3. Funk, V.A.; Susanna, A.; Steussy, T.F.; Robinson, H.E. Systematics, Evolution and Biogeography of Compositae, 1st ed.; International Association for Plant Taxonomy: Vienna, Austria, 2009; pp. 171-189.

4. Villaseñor, J.L. Diversidad y distribución de la familia Asteraceae en México. Bot. Sci. 2018, 96, 332-358. [CrossRef]

5. Villaseñor, J.L.; Rosell, J.A.; Ortíz, E. Plant families as predictors of plant biodiversity in México. Diversity Distrib. 2007, 13, 871-886.

6. Velasco, J.; Barreto, S.; Buitrago, D.; Vivas, R. Antimicrobial activity of extracts from Ageratina neriifolia (Asteraceae). Ciencia 2006, 14, 411-414.

7. Lima, T.C.; Santos, A.D.C.; Costa, D.T.M.; Souza, R.J.; Barison, A.; Steindel, M.; Biavatti, M.W. Chromenes from leaves of Calea pinnatifida and evaluation of their leishmanicidal activity. Rev. Bras. Farmacogn. 2015, 25, 7-10. [CrossRef]

8. Del Barrio, G.; Spengler, I.; García, T.; Roque, A.; Álvarez, A.I.; Calderón, S.J.; Parra, F. Antiviral activity of Ageratina havanensis and major chemical compounds from the most active action. Rev. Bras. Farmacogn. 2011, 21, 915-920. [CrossRef]

9. Navarro, V.M.; González, A.; Fuentes, M.; Avilez, M.; Ríos, M.Y.; Zepeda, G. Antifungal activities of nine traditional Mexican medicinal plants. J. Ethnopharmacol. 2003, 87, 85-88. [CrossRef]

10. García, P.; García, S.; Martínez, G.; Scior, R.F.; Salvador, J.L.; Martínez, M.M.; del Río, R.E. Analgesic effect of leaf extract from Ageratina glabrata in the hot plate test. Rev. Bras. Farmacogn. 2011, 21, 928-935. [CrossRef]

11. Sasikumar, J.M.; Doss, A. Antibacterial activity of Eupatorium glandulosum leaves. Fitoterapia 2005, 76, 240-243. [CrossRef]

12. Gómez, F.; Quijano, L.; Calderón, J.S.; Perales, A.; Ríos, T. 2,2-Dimethylchromenes from Eupatorium aschembornianum. Phytochemistry 1982, 21, 2095-2097. [CrossRef]

13. Ríos, M.Y.; Aguilar-Guadarrama, B.; Navarro, V. Two new benzofuranes from Eupatorium aschembornianum and their antimicrobial activity. Planta Med. 2013, 69, 967-970.

14. Romero-Cerecero, O.; Zamilpa, A.; González-Cortazar, M.; Alonso-Cortés, D.; Jiménez-Ferrer, E.; Nicasio-Torres, P.; Aguilar- Santamaría, L.; Tortoriello, J. Pharmacological and chemical study to identify wound-healing active compounds in Ageratina pichinchensis. Planta Med. 2013, 79, 622-627. [CrossRef] [PubMed] 
15. Aguilar-Guadarrama, B.; Navarro, V.; León-Rivera, I.; Ríos, M.Y. Active compounds against tinea pedis dermatophytes from Ageratina pichinchensis var. bustamenta. Nat. Prod. Res. 2009, 16, 1559-1565. [CrossRef] [PubMed]

16. Romero-Cerecero, O.; Rojas, G.; Navarro, V.; Herrera-Arellano, A.; Zamilpa-Álvarez, A.; Tortoriello, J. Effectiveness and tolerability of a standardized extract from Ageratina pichinchensis on patients with tinea pedis: An explorative pilot study controlled with ketoconazole. Planta Med. 2006, 72, 1257-1261. [CrossRef] [PubMed]

17. Sánchez-Mendoza, M.E.; Rodriguez-Silverio, J.; Rivero-Cruz, J.F.; Rocha-González, H.I.; Pineda-Farías, J.B.; Arrieta, J. Antinociceptive effect and gastroprotective mechanisms of 3,5-diprenyl-4-hydroxyacetophenone from Ageratina pichinchensis. Fitoterapia 2013, 87, 11-19. [CrossRef] [PubMed]

18. Vanisree, M.; Lee, C.Y.; Lo, S.F.; Nalawade, S.M.; Lin, C.Y.; Tsay, H.S. Studies on the production of some important secondary metabolites from medicinal plants by plant tissue cultures. Bot. Bull. Acad. Sin. 2004, 45, 1-22.

19. Leathers, R.R.; Davin, C.; Zry, J.P. Betalain producing cell cultures of Beta vulgaris L. Var. Bikores monogerm (red beet)1. Vitro Cell. Dev. Biol. 1992, 28, 39-45. [CrossRef]

20. Ketchum, R.E.B.; Gibson, D.M. Placlitaxel production in suspension cell cultures of Taxus. Plant Cell Tiss. Org. 1996, 46, 9-16. [CrossRef]

21. Vongpaseuth, K.; Roberts, S.C. Advancements in the understanding of paclitaxel metabolism in tissue culture. Curr. Pharm. Biotechnol. 2007, 8, 219-236. [CrossRef] [PubMed]

22. Wink, M.; Alfermann, A.W.; Franke, R.; Wetterauer, B.; Distl, M.; Windhövel, J.; Kron, O.; Fuss, E.; Garden, H.; Mohagheghzadeh, A.; et al. Sustainable bioproduction of phytochemicals by plant in vitro cultures: Anticancer agents. Plant Genet. Res. 2005, 3, 90-100. [CrossRef]

23. Zhou, M.L.; Shao, J.R.; Tang, Y.X. Production and metabolic engineering of terpenoid indole alkaloids in cell cultures of the medicinal plant Catharanthus roseus (L.) G. Don (Madagascar periwinkle). Biotechnol. Appl. Biochem. 2009, 52, 313-323. [CrossRef] [PubMed]

24. Tang, J.C.; Ren, Y.G.; Zhao, J.; Long, F.; Chen, J.; Jian, Z. Shikonin enhances sensitization of gefitinib against wild-type EGFR non-small cell lung cancer via inhibition PFM2/stat3/cyclinD1 signal pathway. Life Sci. 2018, 204, 71-77. [CrossRef] [PubMed]

25. Yazaki, K. Lithospermum erythrorhizon cell cultures: Present and future aspects. Plant Biotechnol. 2017, 34, 131-142. [CrossRef] [PubMed]

26. Chen, C.; Shanmugasundaram, K.; Rigby, A.; Kung, A.L. Shikonin, a natural product from the root of Lithospermum erythorhizon, is a cytotoxic DNA-bindging agent. Eur. J. Pharm. Sci. 2013, 49, 18-26. [CrossRef]

27. Sánchez-Ramos, M.; Marquina-Bahena, S.; Romero-Estrada, A.; Bernabé-Antonio, A.; Cruz-Sosa, F.; González-Christen, J.; Acevedo-Fernández, J.J.; Perea-Arango, I.; Álvarez, L. Establishment and phytochemical analysis of a callus culture from Ageratina pichinchensis (Asteraceae) and its anti-inflammatory activity. Molecules 2018, 23, 1258. [CrossRef]

28. Mathur, S.; Shekhawat, S.G. Establishment and characterization of Stevia rebaudiana (Bertoni) cell suspension culture: An in vitro approach for production of stevioside. Acta Physiol. Plant. 2013, 35, 931-939. [CrossRef]

29. Nigra, H.M.; Alvarez, M.A.; Giulietti, A.M. Effect of carbon and nitrogen sources on growth and solasodine production in batch suspension cultures of Solanum eleagnifolium Cav. Plant Cell Tiss. Org. Cult. 1990, 21, 55-60. [CrossRef]

30. Guadarrama-Flores, B.; Rodríguez-Monroy, M.; Cruz-Sosa, F.; García-Carmona, F.; Gandía-Herrero, F. Production of dehydroxylated betaleins and dopamine in cell suspension cultures of Celosia argenta var. plumosa. J. Agric. Food Chem. 2015, 63, 2741-2749. [CrossRef]

31. Kehie, M.; Kumaria, S.; Tandon, P. Biotechnological enhancement of capsaicin biosynthesis in cell suspension cultures of Naga King Chili (Capsicum chinense Jacq.). Bioproc. Biosyst. Eng. 2016, 39, 205-210. [CrossRef]

32. Singh, M.; Chaturvedi, R. Evaluation of nutrient uptake and physical parameters on cell biomass growth and production of spilanthol in suspension cultures of Spilanthes acmella Murr. Bioproc. Biosyst. Eng. 2012, 35, 943-951. [CrossRef]

33. Sahraroo, A.; Mirjalili, H.M.; Corchete, P.; Balabar, M.; Moghadam, F.M.R. Establishment and characterization of a Satureja khuzistanica Jamzad (Lamilaceae) cell suspension culture: A new in vitro source of rosmarinic acid. Cytotechnology 2016, 68, 1415-1424. [CrossRef] [PubMed] 
34. Pavlov, A.; Werner, S.; Ilieva, M.; Bley, T. Characteristics of Helianthus annuus plant cell culture as a producer of immunologically active exopolysaccharides. Eng. Life Sci. 2005, 5, 280-283. [CrossRef]

35. Patil, R.A.; Kolewe, M.E.; Roberts, S.C. Cellular aggregation is a key parameter associated with long term variability in paclitaxel accumulation in Taxus suspension cultures. Plant Cell Tiss. Org. Cult. 2013, 112, 303-310. [CrossRef] [PubMed]

36. Butenko, R.G.; Lipsky, A.K.; Chernyak, N.D.; Arya, H.C. Changes in culture medium pH by cell suspension cultures of Dioscorea deltoidea. Plant Sci. 1984, 35, 207-212. [CrossRef]

37. An tSaoir, S.M.; Damvoglou, V. The effect of carbohydrate source and $\mathrm{pH}$ on in vitro growth of Vitis vinifera cultivars Black Hamburg and Alvarino. In Physiology, Growth and Development of Plants in Culture; Lumsden, P.J., Nicholas, J.R., Davies, W.J., Eds.; Springer: Dodrecht, The Netherlands, 1994; pp. 94-97.

38. Warhade, I.M.; Badere, S.R. Fusarium oxysporum cell elicitor enhances betalain content in the cell suspension culture of Celosia cristata. Physiol. Mol. Biol. Plant 2018, 24, 285-293. [CrossRef] [PubMed]

39. Fulkarni, M.M.; Bhimsem, A.N.; Sudhakar, G.D.; Ravindra, N.S. Five chromenes from Bledharispermum subsessile. Phytochemistry 1987, 26, 2969-2971. [CrossRef]

40. Proksch, P.; Witte, L.; Wray, V. Chromene Glycosides from Ageratina altzssima. Phytochemistry 1988, 27, 3690-3691. [CrossRef]

41. Tsuno, T.; Niwano, T.; Kakui, Y. Anti-Inflammatory agent containing sterol esters for use in cosmetics, quasi-drugs, pharmaceutical and health food. Jpn. Kokai Tokkyo Koho, JP 2016, 2016196418.

42. Jianbo, L.; Haiging, Z.; Aisa, B.; Akber, H. Antimicrobial and antitumor activities of crude extracts and isolated compounds from Euphorbia humifusa. Asian J. Chem. 2013, 25, 3957-3960.

43. Romero-Cerecero, O.; Román-Ramos, R.; Zamilpa, A.; Jiménez-Ferrer, J.E.; Rojas-Bribiesca, G.; Tortoriello, J. Clinical trial to compare the effectiveness of two concentrations of the Ageratina pichinchensis extract in the topical treatment of onychomycosis. J. Ethnopharmacol. 2009, 126, 74-78. [CrossRef]

44. Nhan, H.N.; Loc, H.N. Production of eurycomanone from cell suspension culture of Eurycoma longifolia. Pharm. Biol. 2017, 55, 2234-2239. [CrossRef] [PubMed]

45. Moradi, A.; Zarinkamar, F.; De Domenico, S.; Mita, G.; Di Sansebastiano, G.P.; Caretto, S. Salycilic acid induces exudation of cronic and phenolics in Saffron suspension-cultured cells. Plants 2020, 9, 494. [CrossRef] [PubMed]

46. Ruta, C.; De Mastro, G.; Ancona, S.; Tagarelli, A.; De Cillis, F.; Benelli, C.; Lambardi, M. Large-scale plant production of Lycium barbarum L. by liquid culture in temporary system and possible application to the synthesis of bioactive substance. Plants 2020, 9, 844. [CrossRef] [PubMed]

47. Thakur, M.; Bhattacharya, S.; Khosla, P.M.; Puri, S. Improving production of plant secondary metabolites through biotic and abiotic elicitation. J. Appl. Res. Med. Aroma 2019, 12,1-12. [CrossRef]

48. Chowdhury, B.L.; Hussaini, F.A.; Shoeb, A. Antiviral constituents from Vicoa indica. Int. J. Crude Drug Res. 1990, 2, 121-124. [CrossRef]

49. Feng, D.; Ling, W.H.; Duan, R.D. Lycopene suppresses LPS-induced NO and IL-6 production by inhibiting the activation of ERK, p38MAPK, and NF-KB in macrophages. Inflamm. Res. 2010, 59, 115-121. [CrossRef]

50. Nicholas, C.; Batra, S.; Vargo, M.A.; Voss, O.H.; Gavrilin, M.A.; Wewers, M.D.; Guttridge, D.C.; Grotewold, E.; Doseff, A.I. Apigenin blocks lipopolysaccharide-induced lethality in vivo and proinflammatory cytokines expression by inactivating NF- $\mathrm{B}$ through the suppression of p65 phosphorylation. J. Immunol. 2007, 179, 7121-7127. [CrossRef]

51. Yasukawa, K.; Yu, S.Y.; Yamanouchi, S.; Takido, M.; Akihisa, T.; Tamura, T. Some lupane-type triterpenes inhibit tumor proportion by 12-O-tetradecanoylphorbol-13-acetate in two stage carcinogenesis in mouse skin. Phytomedicine 1995, 4, 309-313. [CrossRef]

52. Akihisa, T.; Franzblau, S.G.; Ukiva, M.; Okuda, H.; Zhang, F.; Yasukawa, K.; Suzuki, T.; Kimura, Y. Antitubercular activity of triterpenoinds from Asteraceae flowers. Biol. Pharm. Bull. 2005, 28, 158-160. [CrossRef]

53. Puapairoj, J.; Naegchomnong, W.; Kijjoa, A.; Pinto, M.M.; Pedro, M.; Nascimento, M.S.J.; Silva, A.M.S.; Herz, W. Cytotoxic activity of lupine-type triterpenes from Glochidion sphaerogynum and Glochidion eriocarpum two of which induce apoptosis. Planta Med. 2005, 71, 208-213. [CrossRef]

54. Romero-Estrada, A.; Maldonado-Magaña, A.; González-Christen, J.; Marquina-Bahena, S.; Garduño-Ramírez, M.L.; Rodríguez-López, V.; Alvarez, L. Anti-inflammatory and antioxidative effects of six pentacyclic triterpenes isolated from the Mexican copal resin of Bursera copallifera. BMC Complem. Altern. Med. 2016, 16, 422-432. [CrossRef] [PubMed] 
55. Joo, T.; Sowndhararajan, K.; Hong, S.; Lee, J.; Park, S.Y.; Kim, S.; Jhoo, J.W. Inhibition of nitric oxide production in LPS-stimulated RAW 264.7 cells by stem bark of Ulmus pumila L.. Saudi J. Biol. Sci. 2014, 21, 427-435. [CrossRef] [PubMed]

56. Ando, Y.; Oku, T.; Tsuji, T. Platelet supernatant suppresses LPS-induced nitric oxide production from macrophages accompanied by inhibition of NF- $\mathrm{kB}$ signaling and increased arginase-1 expression. PLoS ONE 2016, 11, e0162208-e0162223. [CrossRef] [PubMed]

57. Dong, R.; Yuan, J.; Wu, S.; Huang, J.; Xu, X.; Wu, Z.; Gao, H. Anti-inflammation furanoditerpenoids from Caesalpinia minax Hance. Phytochemistry 2015, 117, 325-331. [CrossRef]

58. Kanwar, J.R.; Kanwar, R.K.; Burrow, H.; Baratchi, S. Recent advances on the roles of NO in cancer and chronic inflammatory disorders. Curr. Med. Chem. 2009, 16, 2373-2394. [CrossRef] [PubMed]

59. Serreli, G.; Melis, M.P.; Corona, G.; Deiana, M. Modulation of LPS-induced nitric oxide production in intestinal cells by hydroxytyrosol and tyrosol metabolites: Insight into the mechanism of action. Food Chem. Toxicol. 2019, 125, 520-527. [CrossRef]

60. Assanga, I.; Gil-Salido, A.A.; Luján, L.; Rosas-Durazo, A.; Acosta-Silva, A.; Rivera-Castañeda, E.G.; Rubio-Pino, J.L. Cell growth curves for different cell lines and their relationship with biological activities. J. Biotechnol. Mol. Biol. Res. 2013, 4, 60-70.

61. Rodríguez-Monroy, M.; Galindo, E. Broth rheology, growth and metabolite production of Beta vulgaris suspension culture: A comparative study between cultures grown in flasks and in a stirred tank. Enzyme Microb. Tech. 1999, 24, 687-693. [CrossRef]

62. Dubois, M.; Gilles, K.A.; Hamilton, J.K.; Rebers, P.A.; Smith, F. Colorimetric method for determination of sugar and related substances. Anal. Chem. 1956, 28, 350-356. [CrossRef]

Publisher's Note: MDPI stays neutral with regard to jurisdictional claims in published maps and institutional affiliations. 